\title{
Modeling Acequia Irrigation Systems Using System Dynamics: Model Development, Evaluation, and Sensitivity Analyses to Investigate Effects of Socio-Economic and Biophysical Feedbacks
}

\author{
Benjamin L. Turner ${ }^{1, *}$, Vincent Tidwell ${ }^{2}$, Alexander Fernald ${ }^{3}$, José A. Rivera ${ }^{4}$, \\ Sylvia Rodriguez $^{5}$, Steven Guldan ${ }^{6}$, Carlos Ochoa ${ }^{7}$, Brian Hurd ${ }^{3}$, Kenneth Boykin ${ }^{3}$ \\ and Andres Cibils ${ }^{3}$ \\ 1 Dick and Mary Lewis College of Agriculture, Natural Resources and Human Sciences, \\ Texas A\&M University-Kingsville, 700 University Blvd., MSC 228, Kingsville, TX 78363, USA \\ 2 Sandia National Laboratories, P.O. Box 5800, Albuquerque, NM 87185, USA; vctidwe@sandia.gov \\ 3 College of Agricultural, Consumer and Environmental Sciences, New Mexico State University, \\ P.O. Box 30003, MSC 3-I, Las Cruces, NM 88003, USA; afernald@nmsu.edu (A.F.); bhurd@nmsu.edu (B.H.); \\ kboykin@nmsu.edu (K.B.); acibils@nmsu.edu (A.C.) \\ 4 Center for Regional Studies, MSC05 3020, 1 University of New Mexico, Albuquerque, NM 87131, USA; \\ jrivera@unm.edu \\ 5 Department of Anthropology (Emerita), MSC01-1040, 1 University of New Mexico, Albuquerque, NM 87131, \\ USA; sylrodri@unm.edu \\ 6 Sustainable Agriculture Science Center at Alcalde, New Mexico State University, 371 County Road 40, \\ P.O. Box 159, Alcalde, NM 87511, USA; sguldan@nmsu.edu \\ 7 Department of Animal and Rangeland Sciences, Oregon State University, 124 Withycombe Hall, Corvallis, \\ OR 97331, USA; carlos.ochoa@oregonstate.edu \\ * Correspondence: benjamin.turner@tamuk.edu; Tel.: +1-361-593-2464; Fax: +1-361-593-3788
}

Academic Editor: Vincenzo Torretta

Received: 9 August 2016; Accepted: 9 October 2016; Published: 13 October 2016

\begin{abstract}
Agriculture-based irrigation communities of northern New Mexico have survived for centuries despite the arid environment in which they reside. These irrigation communities are threatened by regional population growth, urbanization, a changing demographic profile, economic development, climate change, and other factors. Within this context, we investigated the extent to which community resource management practices centering on shared resources (e.g., water for agricultural in the floodplains and grazing resources in the uplands) and mutualism (i.e., shared responsibility of local residents to maintaining traditional irrigation policies and upholding cultural and spiritual observances) embedded within the community structure influence acequia function. We used a system dynamics modeling approach as an interdisciplinary platform to integrate these systems, specifically the relationship between community structure and resource management. In this paper we describe the background and context of acequia communities in northern New Mexico and the challenges they face. We formulate a Dynamic Hypothesis capturing the endogenous feedbacks driving acequia community vitality. Development of the model centered on major stock-and-flow components, including linkages for hydrology, ecology, community, and economics. Calibration metrics were used for model evaluation, including statistical correlation of observed and predicted values and Theil inequality statistics. Results indicated that the model reproduced trends exhibited by the observed system. Sensitivity analyses of socio-cultural processes identified absentee decisions, cumulative income effect on time in agriculture, and land use preference due to time allocation, community demographic effect, effect of employment on participation, and farm size effect as key determinants of system behavior and response. Sensitivity analyses of biophysical parameters revealed that several key parameters (e.g., acres per animal unit or percentage of normal acequia ditch seepage) which created less variable system responses but which utilized similar
\end{abstract}


pathways to that of the socio-cultural processes (e.g., socio-cultural or physical parameter change $\rightarrow$ agricultural profit $\rightarrow$ time in spent in agriculture $\rightarrow$ effect on socio-cultural or physical processes). These processes also linked through acequia mutualism to create the greatest variability in system outputs compared to the remainder of tests. Results also point to the important role of community mutualism in sustaining linkages between natural and human systems that increase resilience to stressors. Future work will explore scenario development and testing, integration with upland and downstream models, and comparative analyses between acequia communities with distinct social and landscape characteristics.

Keywords: acequia irrigation; community sustainability; system dynamics; coupled natural-human systems; connected hydrologic-human systems; dynamic hypothesis; leverage points; model development; sensitivity analysis

\section{Introduction}

Agriculture-based communities of northern New Mexico have survived for centuries despite the challenges of the arid environment in which they reside. This survival has been achieved through a system of community managed irrigation systems, called acequias (derived from Arabic as-sāqiya, meaning water conduit brought to the region by Spanish colonists [1]. The term acequia refers to both the gravity-based infrastructure for diverting river water to agricultural fields as well as to the social organizational structure of community-based water management [2]. Such systems have been described as coupled natural human $(\mathrm{CNH})$ systems [3], where sustainability (i.e., maintenance of system structure and function) is rooted in the connectivity between the natural and human elements within the system. As a CNH system, watershed function and community sustainability are directly linked by acequia irrigation channels, which divert water throughout the floodplain and provides human (e.g., domestic water), agriculture (e.g., crop irrigation and livestock water), ecologic (e.g., riparian habitat support), and hydrologic benefits (e.g., enhanced surface water-groundwater connectivity; aquifer recharge) [4,5].

Acequias have also been described as common pool resource (CPR) systems [4,6], where resources are managed by decentralized user-groups, where decision-making authority does not reside with a central individual but is dispersed to local users. As a CPR system, community member irrigators living along a common acequia (known locally as parciantes, i.e., irrigators), elect three comisionados (i.e., commissioners) and a mayordomo. Commissioners are tasked with accounting for individual irrigator's contribution to ditch maintenance and negotiating water disputes with neighboring ditches. A mayordomo (meaning "ditch boss") manages the annual ditch cleaning and maintains water flow during the irrigation season, approximately March through October. Irrigators are responsible for contributing labor to ditch cleaning and maintenance activities as well as the costs of repair and maintenance. Acequia water is distributed according to rules and customs passed down through the generations and supported by collective knowledge and sense of place imbedded within community members within a specific acequia system $[7,8]$. Connectivity of people, land, and water, expressed as an integrated (whole) system, where management of water distribution and timing drives landscape function and influences community vitality, is critical for the survival of both people and the landscape, as the "success of landscape management practices [are] ultimately determined by engagement of society in working towards sustainable environmental futures" [9]. This social organization creates opportunities for community irrigators to be actively involved in acequia community issues and to build cohesion and reinforce the importance of acequia function that serves as the lifeline of the community.

Historically, traditional acequia communities maintained high engagement levels through two mechanisms. First, families were directly supported by agricultural activities both in the acequia 
and surrounding uplands, which provided timber, grazing for livestock, and hunting and fishing opportunities. This connectivity between people and land and water facilitated the development of a shared querencia (i.e., "love of place"), which reinforced sense of place and traditions of acequia culture. Secondly, costs of leaving the community could be extremely high due to lack of access to basic resources in surrounding region, which made emigration a risky proposition.

Today, however, acequia communities face many challenges to their sustainability, such as climate change, growing populations, challenging economics associated with agricultural production, pressures for economic development, urbanization in the surrounding region, and threats from downstream users to deliver more water (Table 1) [2]. Agricultural production can no longer support the desired standard of living, and increasing urbanization in northern New Mexico has provided economic opportunities outside the traditional community structure. By relocating or commuting to urban centers for work, less time is allocated to agriculture and more land is fallowed (i.e., taken out of production). Over time, fewer irrigators have been involved in seasonal acequia management activities, which threatens the foundation of community structures $[1,2,4,7,8]$. Demand for rural land continues to grow as wealthy individuals from urban cities continue to buy land for telecommuting or retirement purposes, resulting in agricultural and community fragmentation (Table 1). As land prices have risen, and with limited private land available for residential development, residential expansion has primarily occurred on agricultural land, further reducing the already small farms within the floodplain [3]. Less acequia water diversions for agriculture can hinder the delivery of ecosystem goods and services (e.g., groundwater recharge; riparian habitat). Despite these forces, acequia members have maintained a sense of place and remain optimistic about sustaining the traditional acequia systems [2] and have organized new institutions to support acequia sustainability (e.g., the New Mexico Acequia Association founded in 1989).

Table 1. Rio Arriba and Taos counties population and economic growth over time along with changes to the community of Alcalde, New Mexico (case study below). The three regions are home to hundreds of acequia ditches.

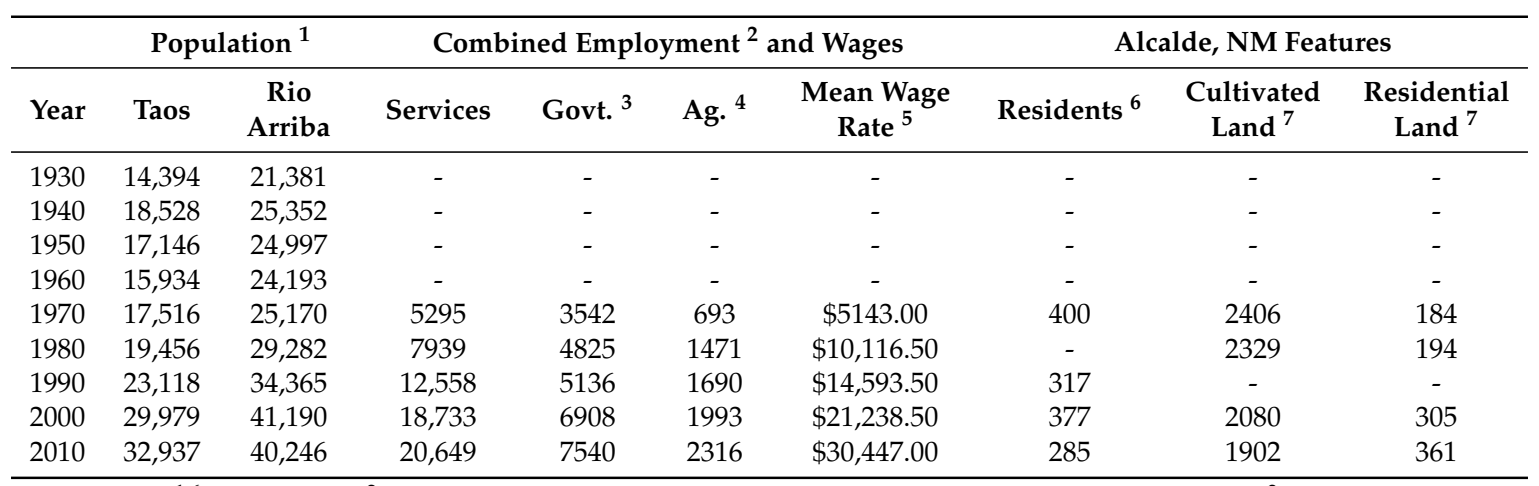

Note: ${ }^{1,6}$ U.S. Census; ${ }^{2}$ Sum of number of persons employed from Taos and Rio Arriba counties; ${ }^{3}$ Government employment; ${ }^{4}$ Agriculture related jobs, U.S. BEA [10,11]; ${ }^{5}$ job-1 year-1, [10,11]; ${ }^{7}$ acres, [12].

Previous acequia investigations have taken a variety of approaches. Much recent work has focused on acequia hydrology, including surface water-groundwater interactions [13], deep percolation and shallow groundwater levels [14], water movement through the vadose zone during irrigation [14], and effects of hydrology on riparian habitat and agroecosystem functions [4]. Other approaches have focused on acequia preparedness for climate change or community restructuring [2], or the economics related to acequia participation, alternative water sources, and land fragmentation impacts on acequia resilience (i.e., the ability of the system to quickly respond to disruptive events) [4]. Interdisciplinary systems approaches $[3,15,16]$ have focused on identifying qualitative connections between hydrology, ecology, community, and economics or quantifying and modeling only one or two of these components. More importantly, this work complements major advances in the field of sociohydrology [17-21], where 
six key components (hydrology, population, economics, environment, socioeconomic sensitivity and collective response) have been proposed and developed [16], adopted and extended to more specific application [18-20], and refined and generalized [20]. Results from such work have provided better understanding of the coupled nature between local societies and their hydrologic context, particularly the governing role of community sensitivity to maintaining hydrologic and ecosystem health and functions through an adaptive management process [17-20].

The objective of this paper was to develop a model of acequia community function. This effort is unique in that it seeks to link social, economic, hydrologic and ecologic dynamics to study natural and social stressors on CNH systems. System Dynamics (SD) was adopted for the modeling platform as it is particularly designed for multidisciplinary systems that express organized complexity [22,23] and evolve over time (for full methodological considerations, see [24]). This approach has been used in other water related research projects [25-30] and is valuable for engaging stakeholders and enhancing communication and management of the problem issue at hand [31-34]. In this paper, we first outline the acequia community study areas and the potential threats to their sustainability. Second, we describe their structure, behavior-over-time, and the development of our Dynamic Hypothesis. Then the SD model is presented, along with the strengths and weaknesses its exhibits based on early diagnostic tests for model confidence. Lastly, we discuss the future research aims of this SD model as well as the context in which it can be used to engage stakeholders to explore alternative adaptive measures for acequia communities in northern New Mexico.

\section{Experimental Methods}

We used SD methodology to integrate the social, economic, ecologic, and hydrologic connections that interact within an acequia community. This relies on systems thinking, which is the ability to generate understanding through engaging in mental model-based processes [30] of the system in question. Insights gathered by engaging stakeholders [2] were enhanced by supplementing expert knowledge from various perspectives of the research team, to align community insights with physically-based processes [3]. This method has been used in previous water-related projects (as described above) and is supported by systems-based methods in ecology and natural resource management [35-37]. Outlined below is the SD process applied towards model development, beginning with the dynamic hypothesis (DH), building up to a working model, model calibration and evaluation, and sensitivity analyses to identify potential leverage points that threaten acequia sustainability.

\subsection{Test Site}

Communities that were established and continue to practice acequia-based management are located throughout New Mexico and southern Colorado, with the majority being in northern New Mexico (Figure 1). These communities lie along the upper and middle Rio Grande basin, including portions of the Rio Chama, Rio Santa Cruz, Taos valley, upper Pecos basin, Albuquerque, and El Paso regions [1]. These drainages generally flow south toward Mexico and Texas with the majority of discharge originating from snow-pack in mountainous watershed reaches. Acequia communities generally lie in small, narrow valleys ("ribbons of green") just below the mountains or along the tributary system that discharges to the Rio Grande corridor. Strong community relationships have been developed at three detailed study sites: Rio Hondo, a tributary to the Rio Grande main stem (near Valdez); El Rito, a tributary to the Rio Chama; and Alcalde, which is on the main stem of the Rio Grande. These sites are excellent for testing regional connections between the Albuquerque urban area on the Rio Grande downstream and the rural study sites upstream. For this study, the Alcalde acequia community system was selected which is located alongside the Rio Grande just north of Santa Fe, New Mexico. This site was selected to take advantage of existing instrumentation and networks of local expertise (e.g., [2,14,15]), however, the model was designed to be extensible to other acequia systems throughout northern New Mexico. The effects of the larger regional socio-economic forces on the Alcalde community are also provided (Table 1). 

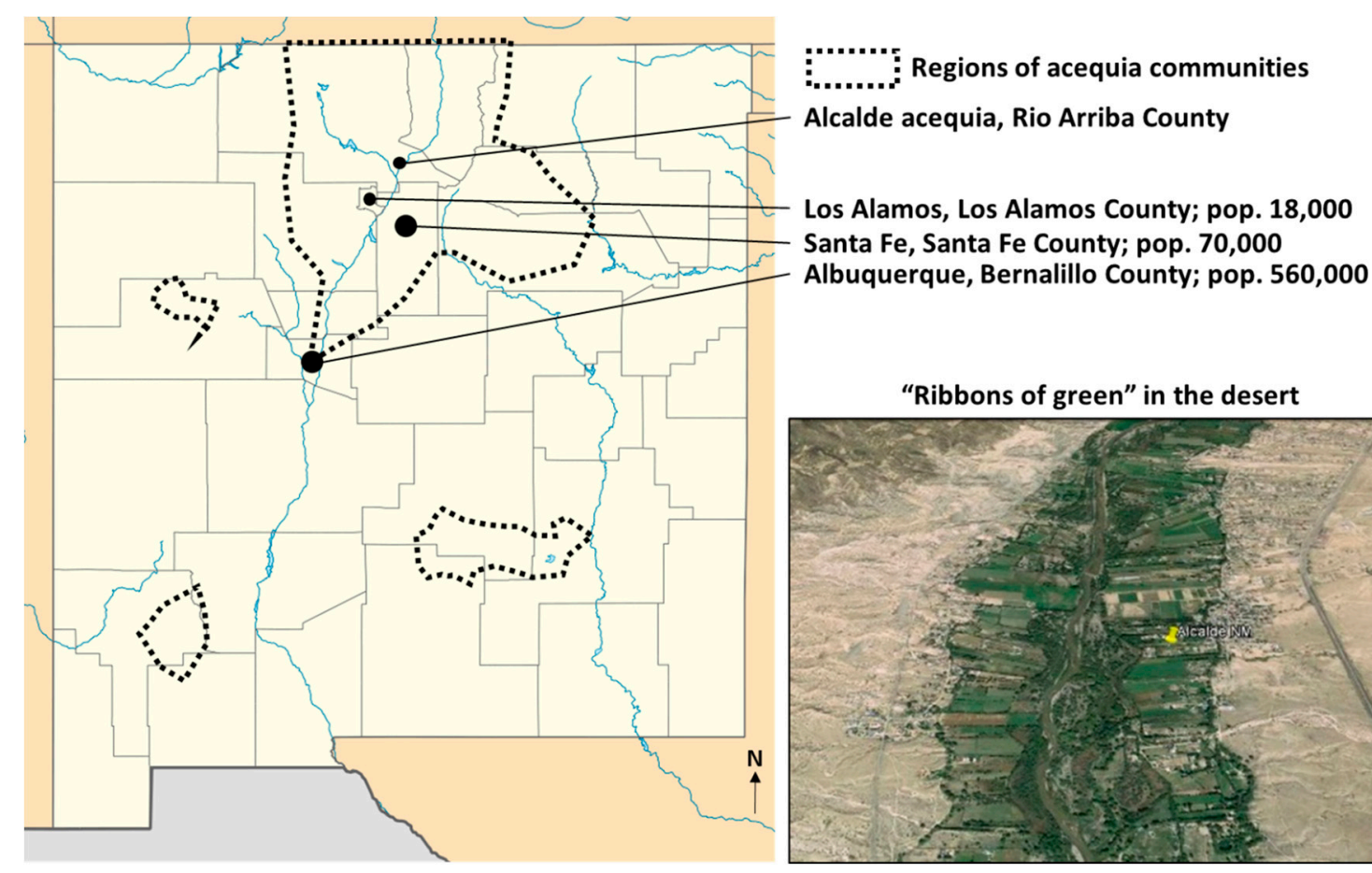

Figure 1. Map of principal acequia regions within New Mexico, USA, showing the Alcalde acequia relative to nearby population centers Los Alamos, Santa Fe, and Albuquerque. The aerial image shows the vegetative landscape, or "green ribbons", that persist in the arid region due to acequia water management. Images provided by [38,39], acequia regions approximated from [40].

\subsection{Dynamic Hypothesis}

The dynamic hypothesis $(\mathrm{DH})$ is a working theory of how the problem of interest arose and should provide an explanation of the problem dynamics in terms of endogenous feedback structures [24]. The DH serves as a theory that links the model and real-world system, integrating relevant knowledge and data about the real-world into a testable framework by which to judge the SD model [41,42]. For this study, our DH was focused on the relationship between community structure and resource management in traditional acequia communities of northern New Mexico. Acequia communities were built on CPR practices, such as sharing uplands resources (e.g., grazing) and water for agricultural production in the floodplains, collective-knowledge transmission to descendants, embedded community mutualism, and cooperation of community members. Mutualism, in this context, can be described as the shared, communal responsibility of local residents to maintaining traditional irrigation policies and upholding cultural and spiritual observances unique to their family and acequia's lineage (e.g., feelings of collective well-belling, social identity, pride and sense of place) and closely resembles community sensitivity state factors expressed in socio-hydrology [18-21] Historically, mutualism was maintained by management activities that connect residents with each other and natural resources. However, mutualism has been threatened due to changing demographics (including family continuity), economic hardship (necessitating external jobs), and agricultural participation rates (declines in land and water devoted to agriculture), which threatens sustainability of acequias through reduced participation in the traditional activities (Figure 2).

Our DH further addresses the problem of eroding mutualism that is driven by three factors. First, land segmentation by intergenerational division of land among children has reduced farm size and profitability, forcing land owners to seek higher wage jobs outside the community and spend less time on agricultural and acequia-related activities (loop R1 in Figure 2). Second, successful intergenerational land transfers maintain familial community ties, but often delays agricultural activities until inheritors return to the land (loop R2 in Figure 2). Third, increasing demand for 
land and water, coupled to the above threats, promote resources being sold or moved out of agriculture in favor of other uses (e.g., residential development; water sold to downstream users), which further segments the community (loop R3 in Figure 2). Consequently, acequia functions are neglected, which threatens the delivery of economic (e.g., agricultural products) and ecosystem goods and services (e.g., provisioning of water; biodiversity in riparian and aquatic habitat, etc.) it provides. Despite these forces, self-organization of remaining community members has worked to enhance political and economic position (balancing loop in Figure 2), helping to protect acequia functions and tradition (e.g., the New Mexico Acequia Association has provided a legislative voice and has worked to preserve acequia traditions). The following sections describe the model, its evaluation against observed data, sensitivity test procedures, and identification of potential leverage points of acequia resilience.

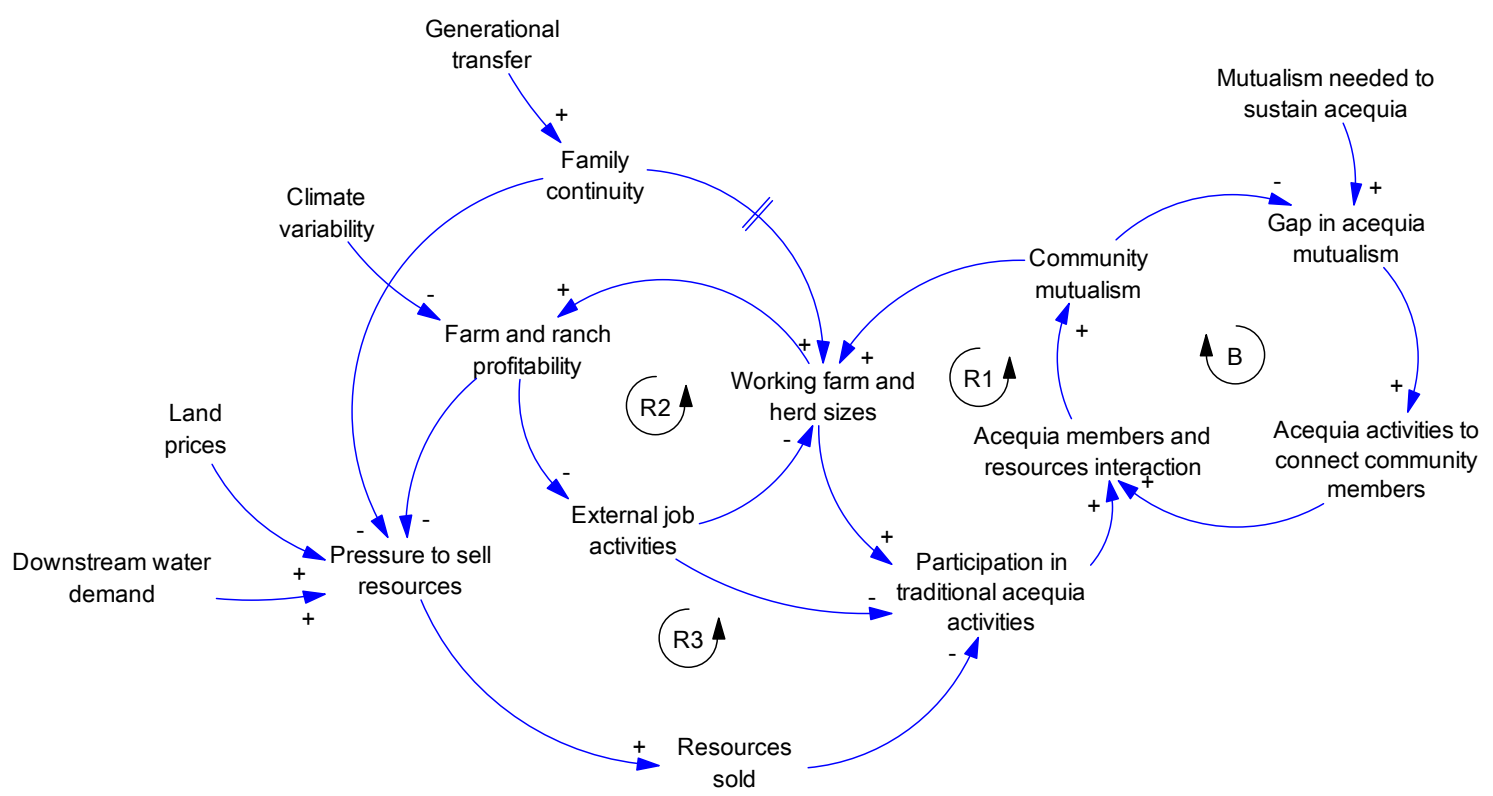

Figure 2. Causal loop diagram of the Dynamic Hypothesis, showing endogenous feedbacks and driving variables that contribute to low levels of participation in traditional acequia activities (double line marks across an arrow represent lengthy time-delays between cause and effect).

\subsection{SD Model Overview}

The SD model incorporates economic, social, ecological and hydrological dynamics (similar to the foundational elements of socio-hydrologic modeling [18-21]), which operate over a fixed land base owned by acequia community irrigators (Figure 3). Endogenous components include land use, time management decisions of individual irrigators, and community population dynamics (Figure 3). Exogenous components include labor wage rates, commodity prices and production costs, stream flows, and annual temperatures, all of which drives agriculture production systems and ultimately irrigators' profitability. The model was formulated using PowerSim Studio ${ }^{\mathrm{TM}}$ V. 10 with a monthly time-step and a 40-year simulation horizon (1970-2010). Below we provide a description of each model component using stocks, flows and auxiliary variables (see Figure S1 for an overview of iconography used in SD model programming). A full list of model variables and equations presented in each component description below are provided in Tables S1-S9 and are referenced within each of the following sections. 


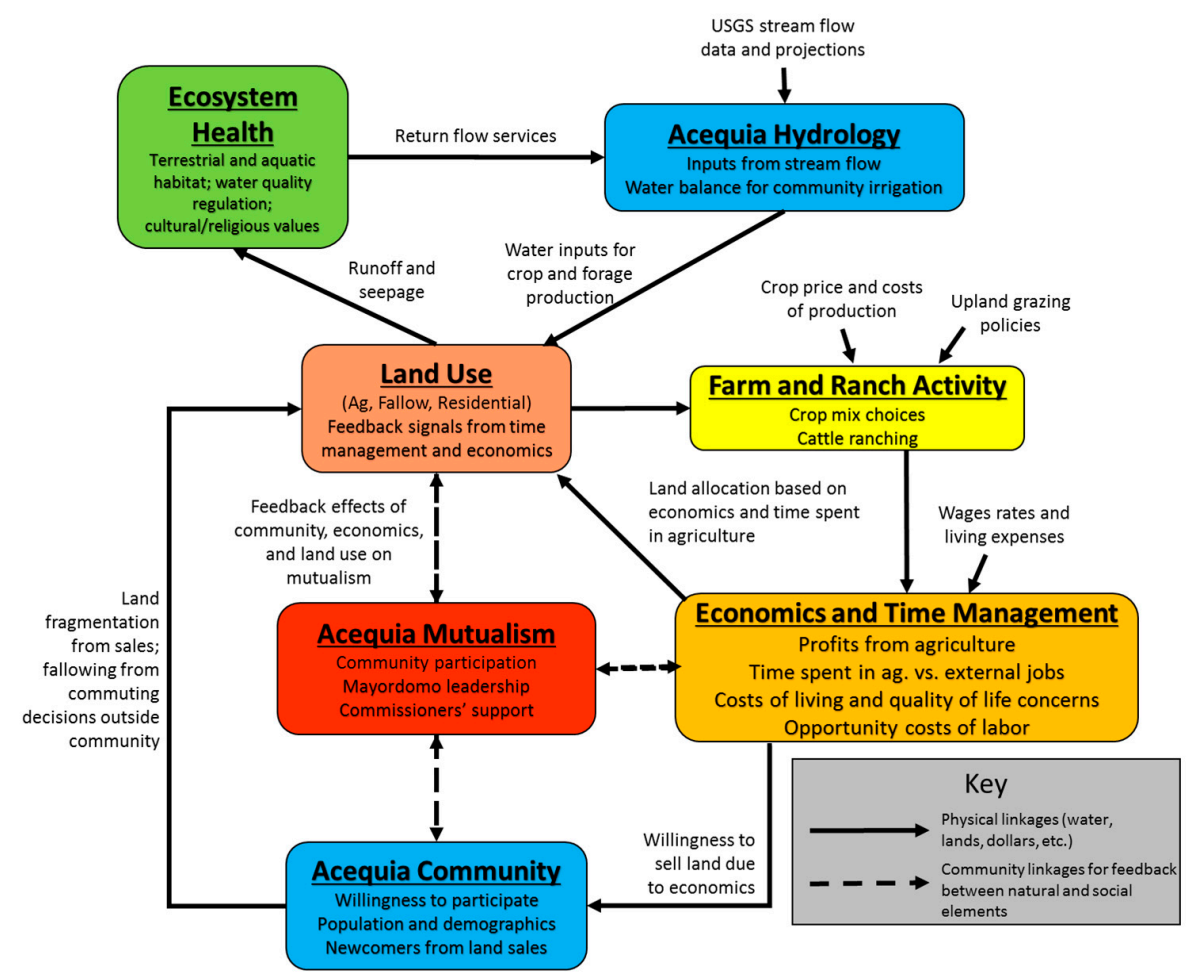

Figure 3. Conceptual diagram showing each system building block of the acequia model and the linkages between them, similar to other socio-hydrology models [18-21]. Building blocks are referenced in corresponding sections of the text and equations for each are provided in Tables S1-S9.

\subsection{Stock-and-Flow Structures for System Building Blocks}

\subsubsection{Acequia Mutualism}

Mutualism was defined as the communal responsibility of local residents to maintaining traditional irrigation practices. There was no definitive measure for this social dynamic. As such, key contributing factors were aggregated to create an index that measured acequia mutualism $[7,8]$ (Figure 4; model variable names have been italicized throughout). Using the variables working farm size, percentage of time spent outside acequia, percentage of community likely to participate in acequia, and fallow land as percentage of total land, we estimated a community participation index. Mutualism increases (building mutualism) by multiplying the current acequia mutualism level (a value ranging from 0 to 1 ) by the community participation index and delaying it by the time needed to build mutualism. If community participation index drops below 1 (an arbitrarily chosen index value based on the input values), the result is eroding mutualism. Acequia mutualism is also influenced by leadership of the mayordomo, since the mayordomo is the central individual linking the community's human dimensions with the function of the ditch. If acequia mutualism drops below a given threshold (need to strengthen acequia leadership), then mayordomo changes are initiated to boost mayordomo strength, thereby facilitating change in community participation index and reducing eroding mutualism. Acequia mutualism feeds back to the other model components through its impact on irrigators' time spent in agriculture function, which is a key variable used across the economics and time management, acequia community, and land use building blocks (Figure 3). Important socio-cultural processes involved included the influence of newcomers to an acequia, where an influx of newcomers reduces participation in traditional activities in the short-term until they are willing to acclimate into the community (community demographic effect on participation), the effect that off-farm employment has on participation, since working off-farm reduces the amount of time irrigators have to commit to the acequia (effect of employment on participation), and the effect of farm size, since reduced time in agriculture limits the amount of land an irrigator 
can farm and therefore their willingness to continue participating in the acequia (farm size effect on participation). Brief descriptions for each socio-cultural variable and visual aid into their connectivity are provided in Section 2.6 (below) and Figure S2.

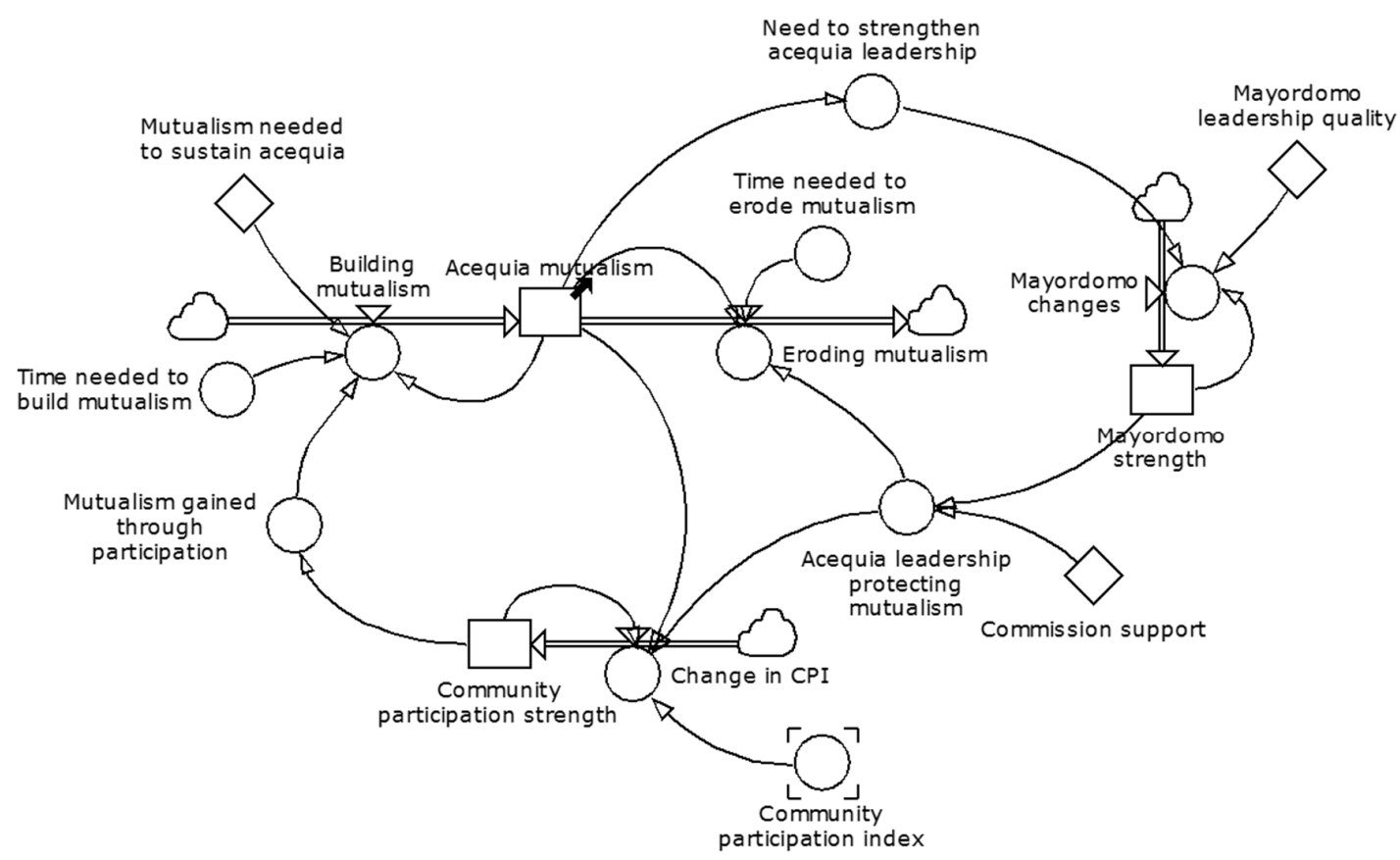

Figure 4. Acequia mutualism structure required by our Dynamic Hypothesis, which ties mutualism and participation in the acequia to the local natural resources and community forces. Equations are provided in acequia mutualism system building block, Table S1.

Mutualism as described here shares a similar context with collective response used in social-hydrologic modeling addressing the key role of cooperation in CHN and CPR systems. However, there are also some important differences. Given that the acequia model was aggregated to the community level (unlike [20] that integrated at the individual irrigator level), conflict within the acequia between individual irrigators was assumed minimal, rather irrigators were assumed toshare a common goal to maintain the acequia (i.e., from a game theory perspective any gains or losses between individual irrigators cancel out when focusing on the aggregate flows at the community level, and since long-term equilibrium is not expected in these systems given social-economic forces acting on the acequia, we were more interested in how those forces shape the whole acequia rather than individual irrigators). Since the model boundary stopped at the acequia boundary, conflict or cooperation between neighboring acequia systems was not included, although we recognize these dynamics exist in the real world, including these dynamics would have significantly increased model complexity.

\subsubsection{Land Use}

Acequia land (Figure 5), which is the total arable land available to the community, was divided into three stocks: land in production, fallow land, and residential land-impervious cover. Land can be transferred between production and fallow depending on management decisions and subject to delays for discontinuing or preparing for production activities. Land use changes are driven by irrigators decision to fallow or cultivate land based on how economically stressed they may be, such that they are more inclined to fallow land if they need to seek off-farm jobs to maintain their livelihoods (land to fallow or produce by percentage). This decision incorporates a number of dynamics, including what the size of their current farm is and how much time it will take to manage it (working farm 
size, i.e., the amount of land they are actively cultivating), if they have enough land to expand or fallow acres while maintaining their current economic condition (adjusted land to fallow or produce), if descendants are planning on returning to the acequia valley (generational transfer effect), if nearby landowners are willing to lease land for production (leased land in production), and how responsive the irrigator is to the changing economic environment (irrigator responsiveness). Land use changes are also driven by land sales of agricultural property as newcomers seeking a rural residence enter the community (acequia land fragmentation rate) that is influenced by homestead size (which is the amount of land an irrigator is working plus any fallow land they are not), the willingness of existing acequia members to sell land (percentage of land sold), and allow newcomers to acclimate to the acequia system (land sales rate and newcomer introduction). As land is developed to accommodate community growth, transfers are made from agricultural production and/or fallow land stocks to the residential stock (loss of ag land and loss of fallow land). Residential land is added when the community grows, from either generational transfer among current families or the addition of new community members when current residents sell land to alleviate economic pressures. The residential land stock acts as a sink where land no longer transfers use. Other important socio-cultural processes influencing land use transfers were the expected profit generated from selling land that would significantly improve an irrigators financial position (cumulative profit-loss effect on land sales), how quickly absentee acequia members return to the community to inherit their stake and protect the land from being sold (generational transfer effect on land sales), the inclination of current irrigators to sell during economically stressed times (short term profitability effect on land sales) or to fallow the land while they devote more time working off-farm to support themselves (land use preference due to time allocation; see Section 2.6 (below) and Figures S3 and S4 for more specific illustrations or descriptions of the dynamic connections).

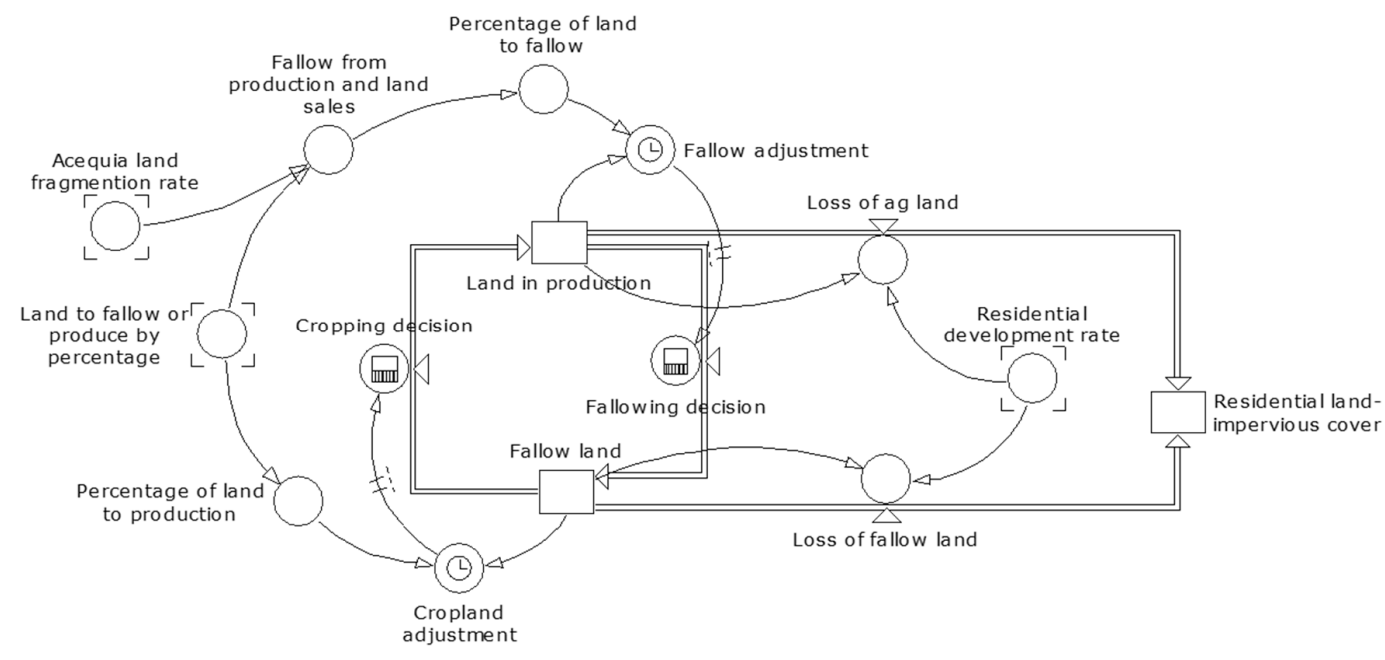

Figure 5. Stock-flow structure of acequia land use. Equations are provided in the land use system building block, Table S2.

\subsubsection{Economics and Time Management}

Community irrigators are constrained by the amount of time they can work per month (i.e., full employment per month; Figure 6). They can work in either their agricultural operation, a job outside the acequia, or some combination of the two. Agricultural production is a priority, but when Agricultural profit-loss (a function of crop and grazing profits) combined with Other income sources is not enough to maintain long-term positive financial savings (Cumulative profit-loss-income met needs or shortfall) irrigators are forced to allocate more time to external jobs to support themselves (hours external per month). The decision to allocate time to agriculture is assumed to be influenced by acequia mutualism, cumulative income effect on time in agriculture (a function of long-term profitability, cumulative profit-lossincome met needs or shortfall), and agriculture time-preference (a function of an individual irrigators 
short-term profitability, Ag profit-loss). The greater each of these factors, the more time irrigators are willing to remain in agriculture. Less time working in the acequia translates into decreased land in production and increased fallow land (through the variable adjusted land to fallow or produce, which depends on current profitability and farm size). If economic conditions improve then percent time in agriculture can be increased by returning land to production. Important socio-cultural processes influencing acequia economics included if irrigators were pressured to work off-farm due to favorable external wages (ratio of wage income in agriculture to external jobs) and the excessive time required to remain in production (absentee decisions), the long-term financial position of the irrigator, since more profitable irrigators can withstand periods of drought or price declines longer than those in a weaker financial position who have to sell land or begin work off-farm (cumulative income effect on time in agriculture, shown as func cieoat in Figure 6), and the mutualism effect that continued community strength incentivizes irrigators to remain involved in production and the acequia activities (mutualism effect on time spent in acequia area valley, shown as func meotia in Figure 6; see Section 2.6 (below) and Figure S5 for more additional descriptions of dynamics included).

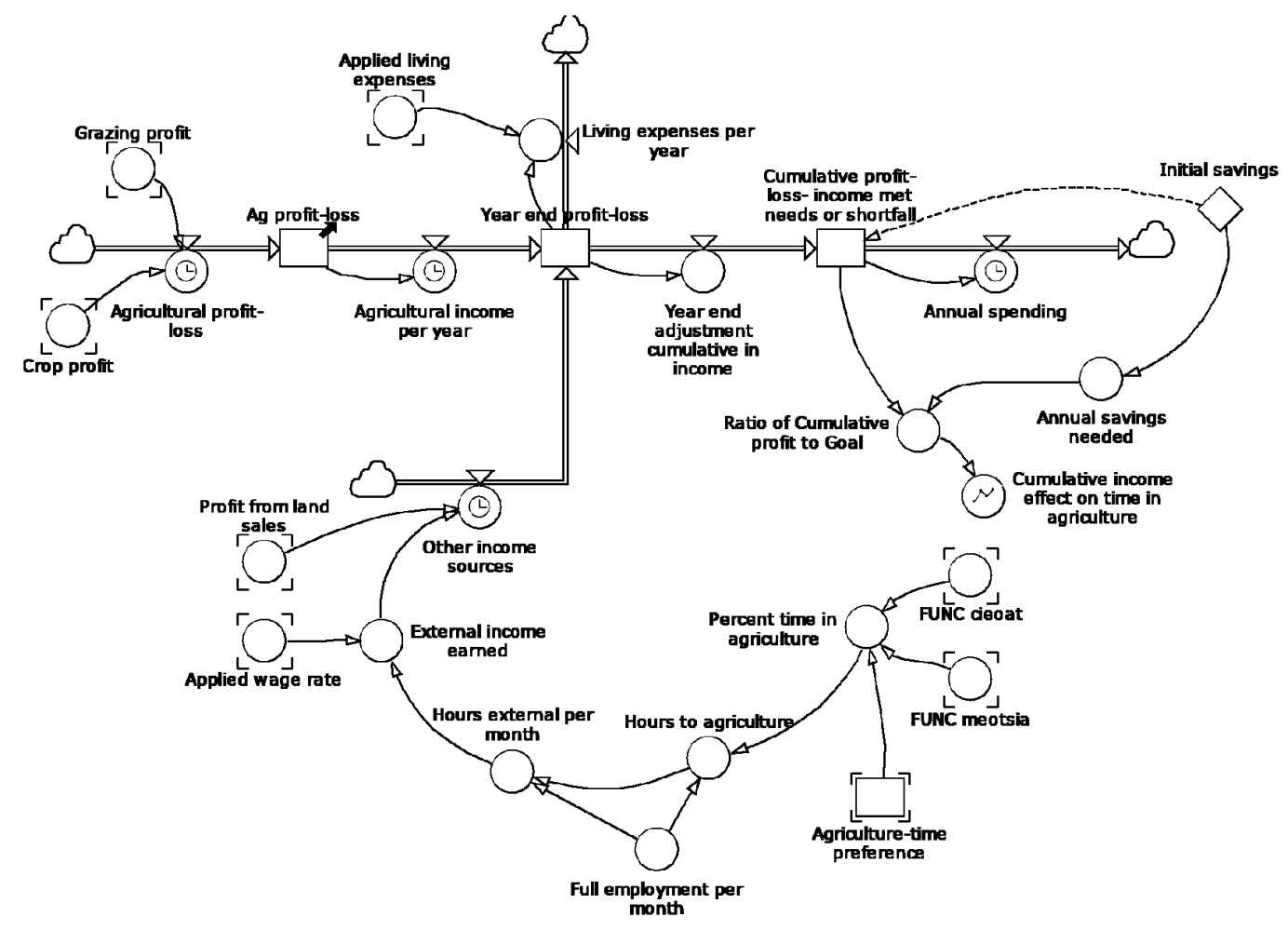

Figure 6. Irrigator time management stock-flow structure with associated feedbacks. Equations are provided in the economics and time management system building block, Table S3.

\subsubsection{Farm and Ranch Activities}

We use a net benefits approach to estimating agricultural profitability which is central to determining how much time irrigators allocate to agricultural (hours to agriculture). Agricultural profit-loss is driven by commodity output, market prices, and costs of production (see farm and ranch activity system building block). Commodity output ultimately influenced land in production (Figure 6) and the ratio of land use types within that stock. Land in production is split into four commodity categories based on current practice [3-6,12]: alfalfa, pasture grass, grains and vegetables, and orchards. Prices and costs of production (both expressed as U.S. dollars per unit, usually lbs.) over time are inserted into the model via linkage with an external spreadsheet. These are multiplied by output for each commodity to arrive at gross revenues and costs of goods sold to determine net benefits from agricultural production. 
The endogenous model components driving net agricultural benefits are percent time in agriculture as well as production yields (which are a function of acreage in use and applied irrigation). Output per unit of land is determined using unique production functions for each commodity with a single independent variable — either irrigation water applied or evapotranspiration (ET; Table 2). These were derived from previous empirical work [43,44]. ET was estimated using Potential Evapotranspiration (PET) and specific crop coefficients (e.g., 1 for pasture grass; 0.71 for orchard; etc.). The PET rate was calculated each month using long-term average temperature data and incoming solar radiation with the Hargreaves method [45-48]. This linked the land and agriculture components with the model's hydrology sector, described below. Besides irrigated agriculture within the acequia, irrigators also rely on revenues from cattle ranching within surrounding uplands (Figure 7). The Cattle herd size stock includes biological replacement and culling rates (Bio culling rate) since it is assumed that the herd would remain at steady state without any management input.

Table 2. Crop production functions.

\begin{tabular}{|c|c|c|}
\hline Crop & Water Production Function & Units of Measure \\
\hline Alfalfa & $\mathrm{y}=0.15+0.13 \times \mathrm{ET}$ & $\mathrm{y}=[$ metric tons $/$ ha $] \mathrm{ET}=[\mathrm{cm}]$ \\
\hline Pasture Grass & $y=-2206+289 z$ & $\mathrm{z}=$ water applied [inches $] \mathrm{y}=$ dry matter $[\mathrm{lbs} / \mathrm{acre}]$ \\
\hline Corn & $y=-7309+238.9 \times E T$ & $\mathrm{y}=[\mathrm{kg} / \mathrm{ha}] \mathrm{ET}=[\mathrm{cm}]$ \\
\hline Grains ${ }^{1}$ & $y=-2323+157 \times E T$ & $\mathrm{y}=[$ metric tons $/$ ha $] \mathrm{ET}=[\mathrm{cm}]$ \\
\hline Miscellaneous Vegetables ${ }^{2}$ & $y=-38.9+135 \times E T$ & $\mathrm{y}=[$ metric tons $/$ ha $] \mathrm{ET}=[\mathrm{cm}]$ \\
\hline Chile Peppers ${ }^{3}$ & $y=-7.54+0.3327 z$ & $\mathrm{y}=[$ ton $/ \mathrm{ha}] \mathrm{z}=$ water applied $[\mathrm{cm}]$ \\
\hline Apple orchard ${ }^{4}$ & $y=35.8853+0.3905 \times E T$ & $\mathrm{y}=[\mathrm{lbs} / \mathrm{acre}] \mathrm{ET}=[\mathrm{cm}]$ \\
\hline
\end{tabular}

Note: ${ }^{1}$ The production function for barley; ${ }^{2}$ The production function for onions; ${ }^{3}$ The average of the production function of green chile $(y=-12.1+0.5168 \times$ water applied $[\mathrm{cm}])$ and red chile $(y=-2.98+0.149 \times$ water applied [cm]); ${ }^{4}$ from [41].

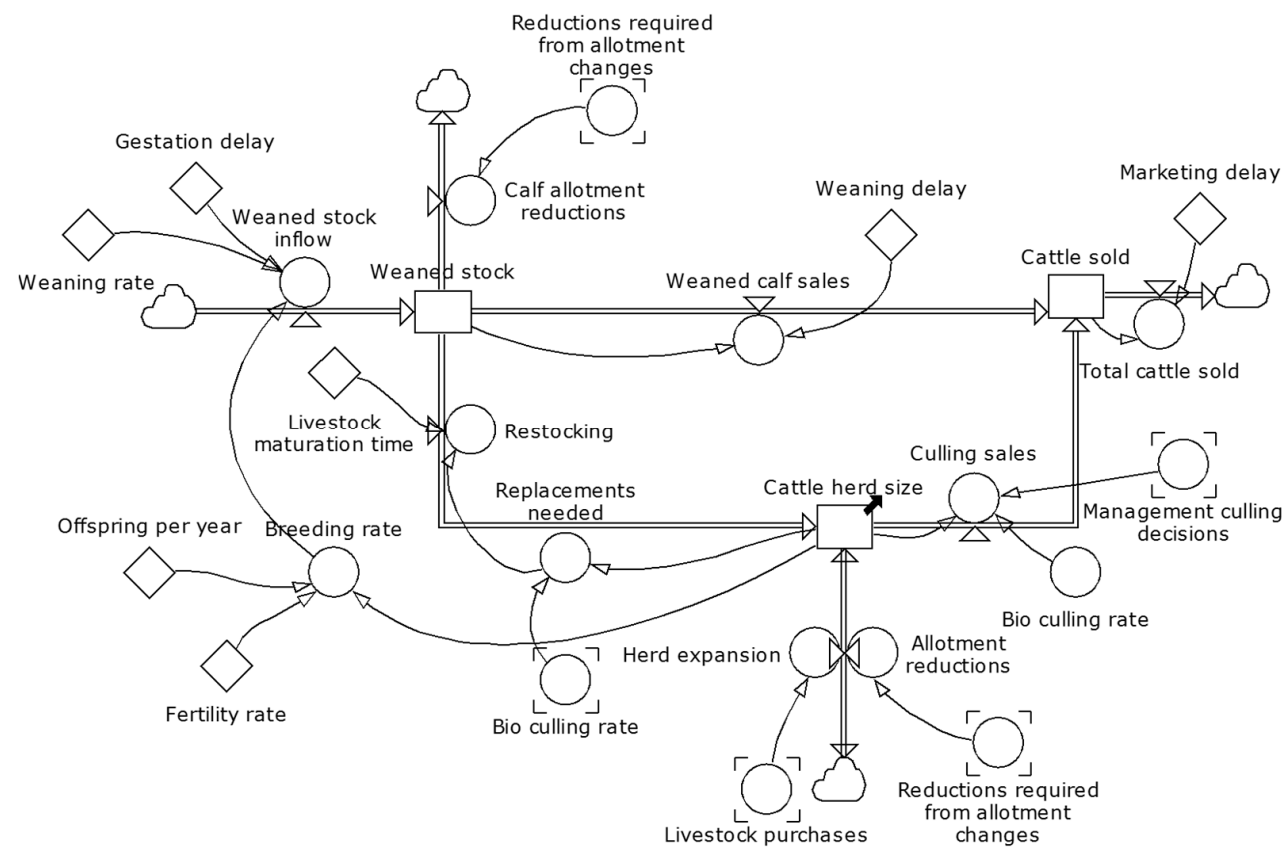

Figure 7. Cattle production stock-and-flow structure for local ranching of community irrigators owning beef livestock. Equations are provided in farm and ranch activities system building block, Table S4.

Changes in Cattle herd size was influenced by restocking, culling sales, herd expansion, upland grazing area (assumed constant) and U.S. Forest Service and Bureau of Land Management grazing permits (Reductions required from allotment changes), which influenced forage accessibility and therefore stocking decisions. Likewise, drought effects also reduce total forage production which necessitated 
management culling decisions (see farm and ranch activity system building block). Herd management is also influenced by profitability and percent time in agriculture due to the labor required to maintain a herd, which was parameterized as a graphical function herd reductions from reduced management (Section 2.6), which was later used in sensitivity testing. Since cattle must be fed through the winter months when forage from upland grazing is no longer available some alfalfa and pasture grass production that is harvested in the summer and fall are stored to feed livestock (Forage reserved; Figure 8). If the amount of Forage reserved does not equal annual winter feed demand then the difference is accounted for by purchased winter feeds. This linked management of the irrigated acequia floodplains with upland grazing allotments, both of which are vitally important to sustaining profitability and functional acequia communities (for additional illustration included in the farm and ranch activities see Figure S6).

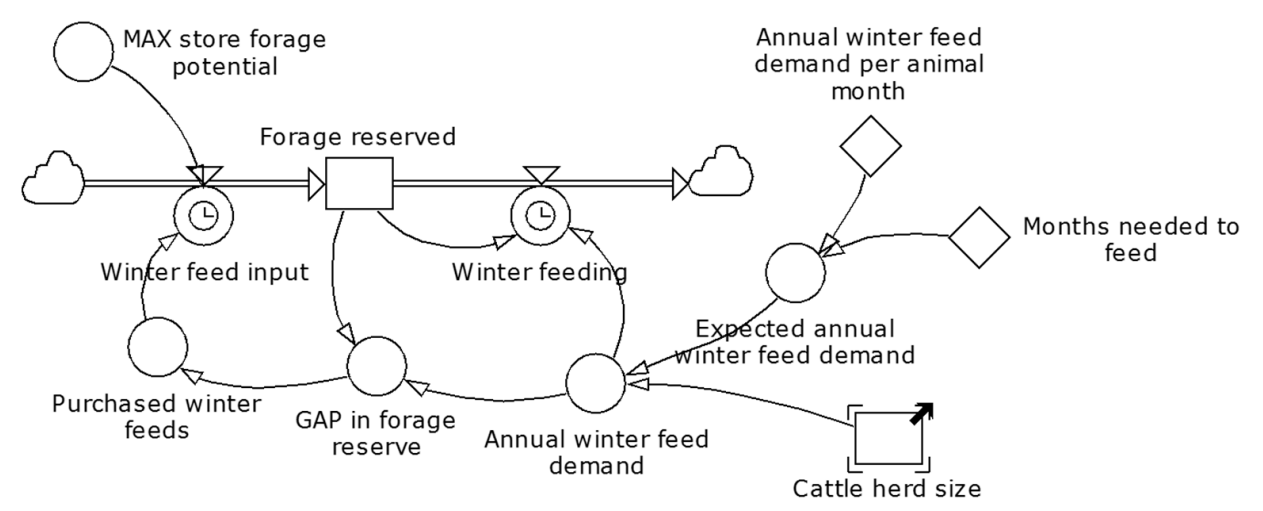

Figure 8. Forage inventory stock-flow structure providing linkages between land use (MAX store forage potential), herd decisions (cattle herd size), economics (purchased winter feeds), and time in agriculture (months needed to feed) for community irrigators owning beef livestock. Equations are provided in the farm and ranch activity system building block, Table S5.

\subsubsection{Acequia Hydrology}

The hydrology sector (Figure 9) begins at the uppermost boundary of the model where the river enters the community (Stream gauge monthly flow rate) and the diversion point for the ditch. Acequia water flow is seasonal, beginning in spring with upland snow melt (March to April; after completion of the ditch cleaning) and ends after the irrigation season (November). Parameters for ditch acequia water flow, monthly flow adjustment, crop field runoff (a surface return flow), ditch acequia seepage and crop seepage (groundwater inflows), and upland source recharge were estimated from previous empirical work $[5,13,14,45]$. Ditch flow volume was partitioned into ditch acequia seepage, crop seepage and crop field runoff, and surface water losses (see acequia hydrology system building block). Estimated water diversion percentage, crop seepage and crop field runoff were based on land in production, estimated water diverted per acre, and irrigation water applied (which was determined by the consumptive irrigation requirement-CIR). The CIR was defined as the amount of water approved as beneficial use in irrigation based on crop ET demand and given water supplies (i.e., precipitation, soil moisture, and groundwater). Determined by New Mexico state policy, CIR values vary by crop (Table 3). When CIR is lower than the irrigation water applied at the field level, the CIR is used as the crop production function input, otherwise irrigation water applied constrains the amount of water used for production. Crop ET and surface water evaporative losses were surface water losses from monthly stream flow. Any unused water at the end of the ditch is a return flow to the river. Seepage and recharge values were Shallow groundwater inflows while the outflow was groundwater head reduction (Figure 10), a function of both consumptive (bosque riparian water demand and rural domestic pumping) and non-consumptive (darcian flow) flows. Darcy flow was a function of the river aquifer head gradient, reach length, and hydrologic conductivity, K. Fluvial aquifer head was based on assumptions of aquifer 
area and specific yield, while river head was estimated based on equations fitted to existing data for river flow (Alcalde river stage estimation) and assumptions for river bottom elevation (for additional illustrations of connections included see Figures S7 and S8).

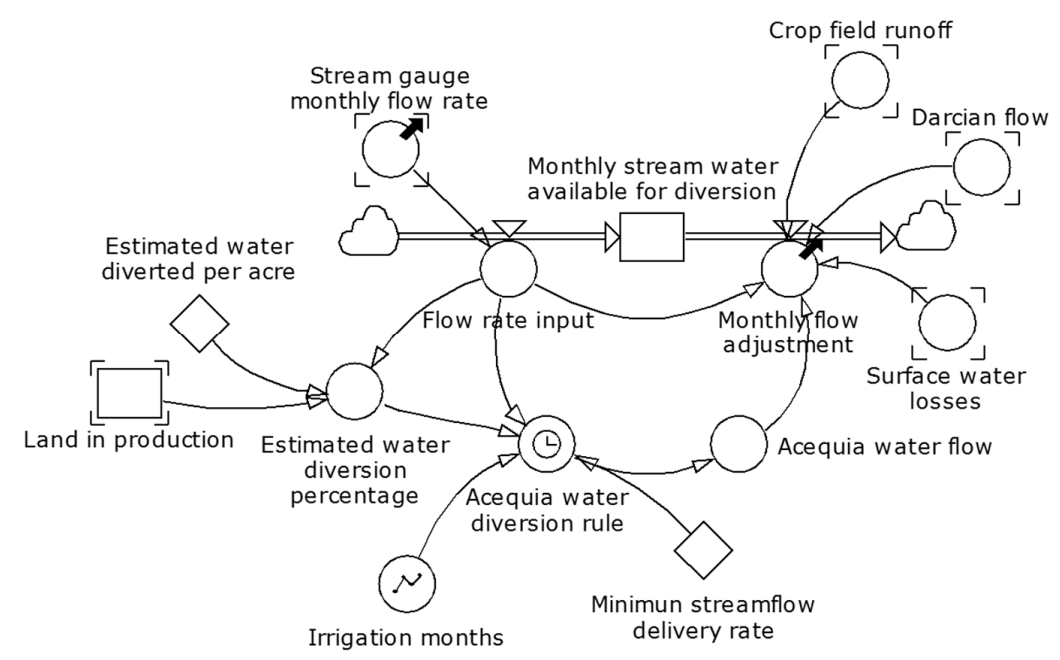

Figure 9. Acequia diversion with feedbacks for return flow gains and surface water losses. Equations are provided in the acequia hydrology system building block, Table S6.

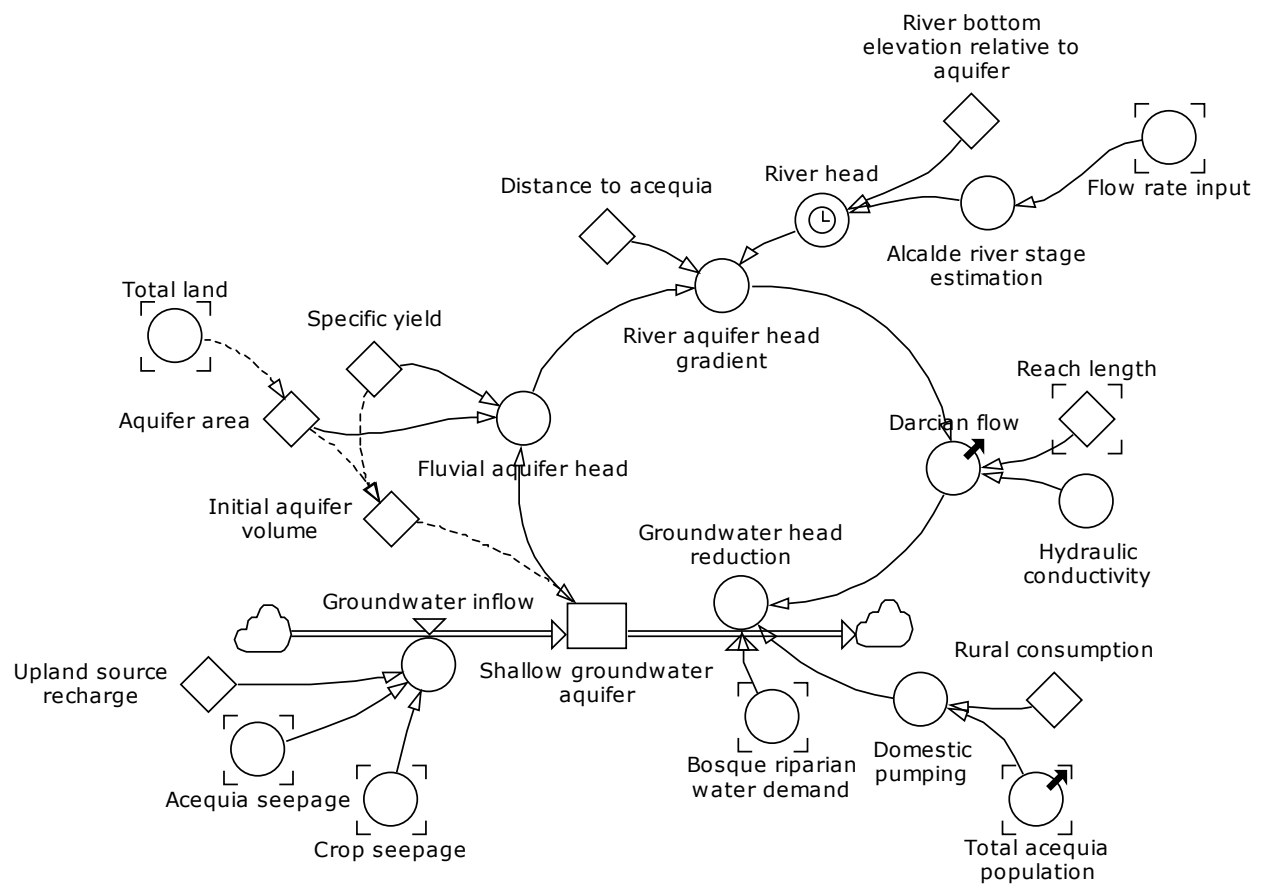

Figure 10. Surface water: groundwater dynamics illustrating riparian vegetation uptake, groundwater extractions, and recharge (including acequia ditch and crop seepage). Equations are provided in the acequia hydrology system building block, Table S7.

Table 3. Acequia consumptive irrigation requirement (CIR) $\left(\mathrm{cm} \cdot \mathrm{month}^{-1}\right)$ used in crop production functions. Only months April through October are shown as these are the irrigation season, all other months are $0 \mathrm{~cm}$ per month.

\begin{tabular}{ccccccccc}
\hline Crop-Type & April & May & June & July & August & September & October & Total \\
\hline Orchards & 4.5 & 4.5 & 4.5 & 4.5 & 4.5 & 4.5 & 4.5 & 31.5 \\
Non-orchard & 5.6 & 5.6 & 5.6 & 5.6 & 5.6 & 5.6 & 5.6 & 39.4 \\
\hline
\end{tabular}




\subsubsection{Ecosystem Health}

Riparian habitat (Figure 11) is important for an array of ecosystem services (e.g., migratory and native bird habitat, erosion protection, carbon sequestration, etc.) and is therefore a key indicator of ecosystem health. In acequia-managed areas, riparian habitat is supported by water inputs from ditch acequia seepage, crop seepage, crop field runoff, and streamflow (see acequia hydrology system building block). These flows were summed to estimate if water inflows available for riparian uptake were sufficient to cover riparian demand (Riparian water needs met?, which includes a calculation for evapotranspiration of the riparian gallery along the river). If inflows were sufficient, then a new riparian habitat value was calculated (estimated change in riparian area), allowing growth to occur (subject to riparian growth rate). If not, then a reduction in riparian habitat was calculated subject to the natural riparian longevity-drought tolerance. Change in riparian area approached 0 when riparian habitat reaches its maximum potential (i.e., bosque area + percentage of other land riparian) or becomes negative when water becomes limiting (i.e., riparian water demand was not met). Neglected or poorly managed farmland functions similarly to (e.g., near the stream and ditch channel as agricultural Fallow land, shown as the percentage of other land riparian), riparian habitat; therefore, the bosque area and the percentage of other land riparian provided constraints on how large or small the riparian habitat could become.

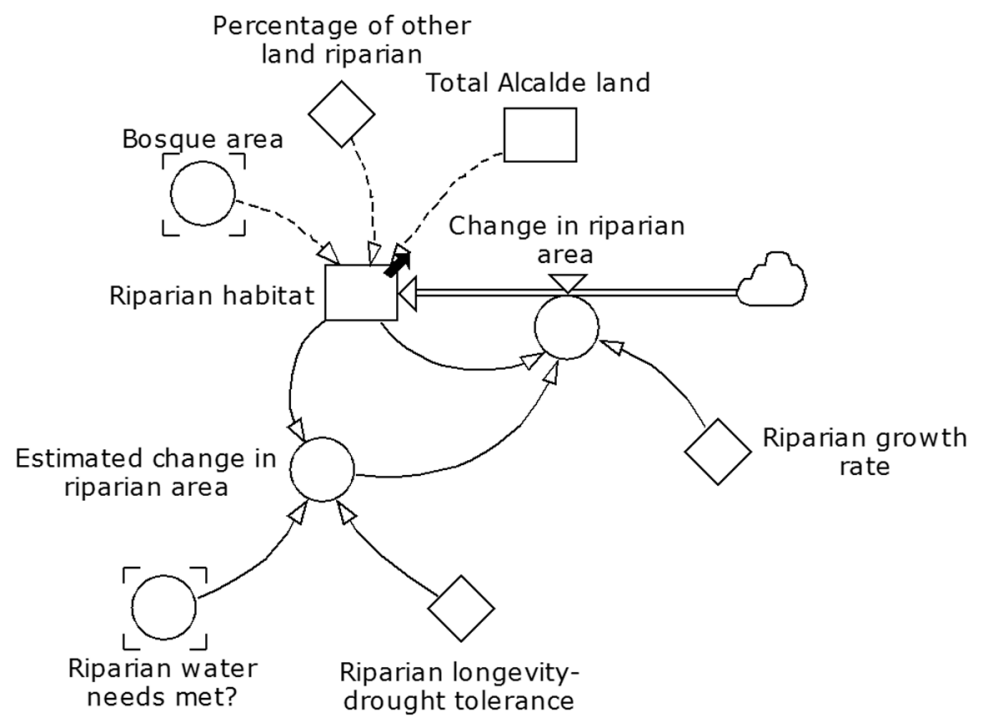

Figure 11. Ecosystem health model. Equations are provided in ecosystem health system building block, Table S8.

\subsubsection{Acequia Community}

The final endogenous component of the model is the acequia community Total population (simplified in Figure 12). This component distinguished native acequia members by age and newcomers by participation in the community. Total population was comprised of a three stock aging chain: acequia youth, acequia members, and acequia elders (see the acequia community system building block). Because some irrigators have to work full- or part-time in an external job (described above), not all community members will participate in acequia management activities. This was included by an additional stock, absentee acequia members, to allow youth or current members to flow between active and passive participation in the community. When land is fragmented by irrigators selling property, newcomers to acequia are introduced that require time to acclimate to the acequia. This required a fifth stock of new-comers to be added to the aging chain that incorporated land sales and fragmentation and acclimation of new acequia members. Important socio-cultural processes also influencing the community dynamics were the reduced rate of newcomers as the availability of new home sites diminished due to previous land fragmentation associated with development (homestead size effect of reducing urban 
expansion; see Table 4 for additional descriptions of the dynamic connections included), which adjusted the rate in newcomers into the acequia based on homestead property size.

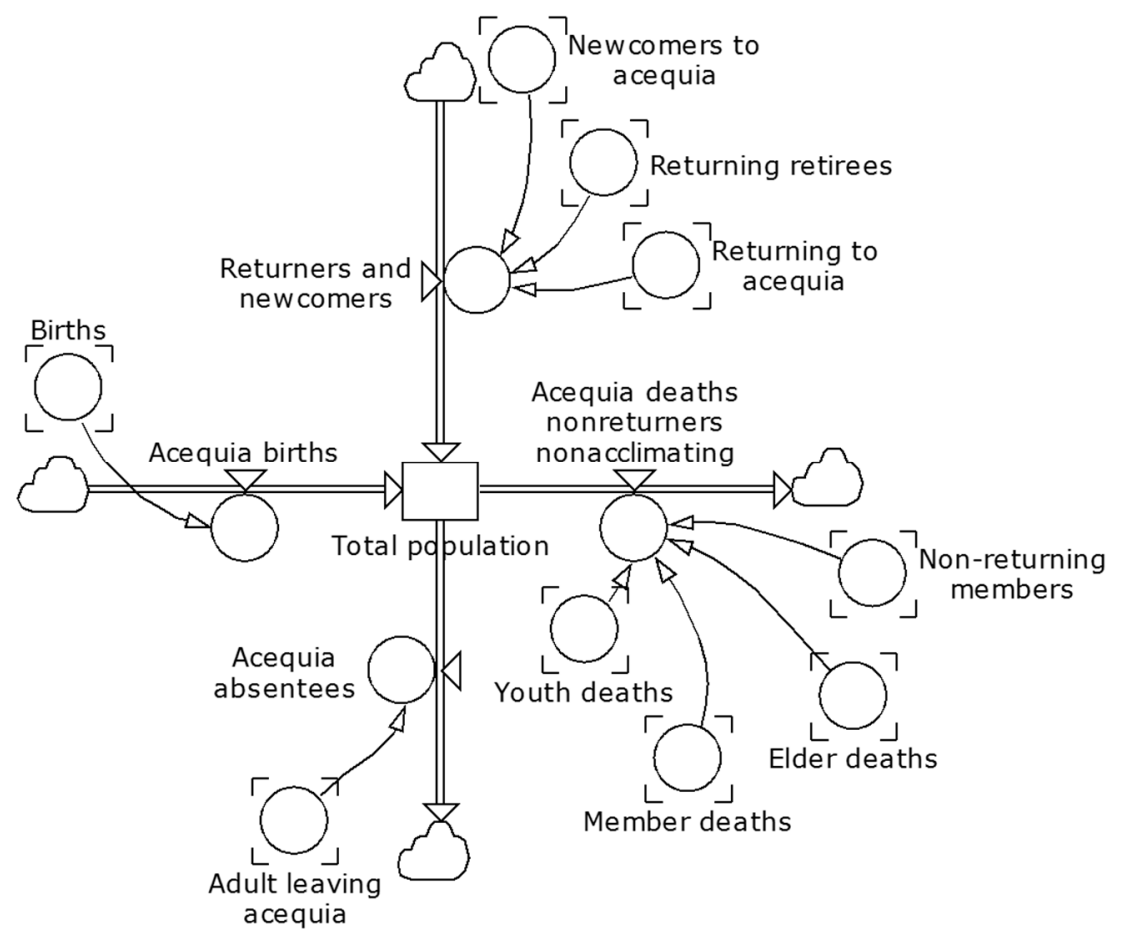

Figure 12. Simplified acequia community dynamics, which includes interactions for in- and out-migration of community members and addition of new members through land sales. Equations are provided in the acequia community system building block, Table S9.

\subsubsection{Exogenous Model Inputs}

Exogenous model inputs included monthly temperatures, stream flow levels driven by snowpack in surrounding uplands and mountains, and external economic components of wage rates, commodity prices, and production input costs (similar to [18-21]). Stream flow levels for each calendar month were derived from long-term river flow data available from U.S. Geological Survey. Agricultural economic inputs (alfalfa prices for hay production, wheat prices as a proxy for all grain and vegetable production, and cattle prices for ranching) were sourced from United State Department of Agriculture (USDA), while orchard (apple) prices were estimated from Washington Growers Clearinghouse (New Mexico orchard data were missing or inconsistent). Wage rates were derived from U.S. Bureau of Economic Analysis $[10,11]$.

\subsection{Model Reference Modes, Calibration, and Evaluation Procedures}

In order to calibrate the model several reference modes needed to be established. Reference modes are variables within the real world system with known behaviors over time (i.e., longitudinal data) for which model outputs could be compared. The model's reference modes include Rio Grande stream flows from above and below Alcalde, NM, agricultural profits [10,11], community size and demographics, and land use (agricultural, long-term fallow, and residential land; riparian habitat; [12]); reliable reference model data that could be compared to Acequia mutualism were not readily available and remains an area for future data collection. Each of the above reference modes were chosen because: (a) it represented an important measure related to acequia community resilience; (b) its calculation depended on inputs from across multiple model building blocks (Figure 3); and (c) readily available data existed which would facilitate comparison to model outputs. 
Each of the above model outputs were compared to the available historical data. The reference mode time horizon was the time period 1969 through 2008 (social and land use components) and 1969 through 1985 (hydrology components). The major methods we used for judging model adequacy included behavior reproduction tests and Theil inequality statistics (a method of decomposing Mean Square Error, MSE, of predicted values). In general, errors in mean (i.e., proportion of model error arising from the mean $=1$ and variance and covariance $=0$ ) are serious indicators of flawed parameter estimation, errors in variance (i.e., the proportion of model error arising from variance $=1$ and mean and covariance $=0$ ) indicate that the magnitude of variation around the means differ, and large errors in covariance (i.e., the proportion of model error arising from covariance $=1$ and mean and variance $=0$ ) indicate that mean and variance discrepancies are small but point-by-point estimates do not match $[24,49,50]$. Ideally, model results of ending Theil values should be small and unsystematic (i.e., low errors in mean and variance, with most errors concentrated in the covariance percentages) [24,42]. To gauge effective fit between observed and model predicted data, we combined the Theil performance with correlation coefficient $\left(\mathrm{r}^{2}\right)$ and mean bias. Although additional tests can be included in model evaluations $[24,42,51]$, presenting all such tests is beyond the scope of this paper.

\subsection{Sensitivity Analyses}

Stakeholder analyses or other published reports $[1,2,4,7,8]$ have described the major role that socio-cultural components have in maintaining acequia systems. For many of the socio-cultural processes (see Table 4 which includes key variables and their location within the system building blocks (Figure 3)), little or no guidance on dynamic structure or data exist for model formulation. Due to the importance and uncertainty around the form of these socio-cultural processes a comprehensive sensitivity analysis was then performed. In total, there were 13 socio-cultural processes of interest, which yielded 46 different parameter coefficients (Table 4). First, each parameter was screened by a quasi-traditional sensitivity approach by multiplying the output of the analytical form across a range -10 to 10 (or an order of magnitude, since most of the original graph functions yielded values between zero and one). Although this range may not have been realistic in the sense it matched real world observations, it was anticipated that such a large range would be able to capture significant model behavior changes not observed during the calibration process, which could possibly reveal some additional insight into the model's structure. Results of sensitivity runs were compared to the original model calibration errors, measured as Root Mean Squared Error (RMSE), to identify significant behavior-pattern changes in model outputs (agricultural, fallow, and residual land; stream flow; acequia community population; and agricultural profits). Parameters that did not cause a shift in model behavior (i.e., RMSE did not vary from the calibrated simulation) were eliminated from further screening.

After initial screening, the remaining parameters were tested by distorting the graphical (now analytic) function point-by-point by altering each coefficient of the equation independently, thereby changing the shape of the original distribution [52]. In order to maintain the sign of each coefficient in the equation, values were multiplied by the range zero to 10 . Similar to the first sensitivity screening, parameters that caused no change in calibrated model behavior (i.e., RMSE did not significantly vary) were eliminated. The final remaining parameters were determined to be the most effective in altering model behavior. Systemic effects that these parameters had on calibration variables could then be described as either numerically sensitive (i.e., produced similar trends with slightly different values) or behaviorally sensitive (i.e., produced trends with noticeably different values), and were of interest for optimization procedures yielding equally credible coefficient values. 
Table 4. List of socio-cultural processes captured in the model first using graphical, then analytic equations [conceptual development supported by source material in $2-3,6-8$, and expert knowledge provided by all co-authors].

\begin{tabular}{|c|c|c|c|c|}
\hline Qualitative Parameters & Input Variable $(\mathrm{x})$ & Analytic Equation & Description of Dynamics Captured & System Building Block \\
\hline Absentee decisions & $\begin{array}{l}\text { Agriculture-time } \\
\text { preference }\end{array}$ & $y=-0.377 x^{3}+0.991 x^{2}-0.9214 x+0.2964$ & $\begin{array}{l}\text { Captures acequia members willing to commute or relocate based on } \\
\text { the opportunity cost of labor. }\end{array}$ & $\begin{array}{c}\text { Economics and } \\
\text { Time Management }\end{array}$ \\
\hline $\begin{array}{l}\text { Community demographic } \\
\text { effect on participation }\end{array}$ & $\begin{array}{l}\text { Percentage of community } \\
\text { likely participating }\end{array}$ & $y=4.3125 x^{2}-4.171 x+1.012$ & $\begin{array}{l}\text { Captures influence of irrigators remaining in agriculture to maintaining } \\
\text { mutualism or the impact newcomers have on lowering mutualism. }\end{array}$ & Acequia Mutualism \\
\hline $\begin{array}{l}\text { Cumulative income } \\
\text { effect on time in agriculture }\end{array}$ & $\begin{array}{l}\text { Ratio of Cumulative } \\
\text { Profit to Goal }\end{array}$ & $\mathrm{x}<0 \rightarrow 0 \rightarrow \mathrm{y}=1.31 \mathrm{x}-0.001$ & $\begin{array}{l}\text { Captures the dynamics that total income (farm and off-farm) has on } \\
\text { irrigator's resiliency to remain in agriculture under adverse } \\
\text { economic conditions. }\end{array}$ & $\begin{array}{l}\text { Economics and } \\
\text { Time Management }\end{array}$ \\
\hline $\begin{array}{l}\text { Cumulative profit-loss } \\
\text { effect on land sales }\end{array}$ & $\begin{array}{l}\text { Ratio of Cumulative } \\
\text { Profit to Goal }\end{array}$ & $y=0.0744 x^{2}-0.1162 x+0.047$ & $\begin{array}{l}\text { Captures the long-term financial pressure to sell land in order to } \\
\text { maintain quality of life. }\end{array}$ & Land Use \\
\hline $\begin{array}{l}\text { Effect of employment } \\
\text { on participation }\end{array}$ & $\begin{array}{l}\text { Percentage time } \\
\text { outside acequia }\end{array}$ & $y=-4.137 x^{4}+5.294 x^{3}-0.34 x^{2}+0.152 x$ & $\begin{array}{l}\text { Captures the effect that increased time in off-farm jobs has on } \\
\text { decreasing time spent on acequia activities. }\end{array}$ & Acequia Mutualism \\
\hline $\begin{array}{l}\text { Farm size effect } \\
\text { on participation }\end{array}$ & Working farm size & $y=-0.0024 x^{3}+0.051 x^{2}-0.3629 x+0.91$ & $\begin{array}{l}\text { Captures the influence of farm size has on participation, since smaller } \\
\text { farms likely need off-farm financial support and therefore irrigators } \\
\text { have less time to participate. }\end{array}$ & Acequia Mutualism \\
\hline $\begin{array}{l}\text { Generational transfer } \\
\text { effect on land sales }\end{array}$ & Transfer rate goal & $y=-0.063 x^{3}+0.1203 x^{2}-0.079 x+0.02$ & $\begin{array}{l}\text { Captures the effect that keeping land in the family has on } \\
\text { reducing land sales. }\end{array}$ & Land Use \\
\hline $\begin{array}{l}\text { Herd reductions from } \\
\text { reduced management }\end{array}$ & $\begin{array}{l}\text { Percentage time } \\
\text { in agriculture }\end{array}$ & $y=-0.2367 x^{3}+1.558 x^{2}-2.142 x+0.84$ & $\begin{array}{l}\text { Captures the effect that less time in agriculture has on the ability to } \\
\text { maintain historical herd levels. }\end{array}$ & $\begin{array}{c}\text { Farm and } \\
\text { Ranch Activities }\end{array}$ \\
\hline $\begin{array}{l}\text { Homestead size effect of } \\
\text { reducing urban expansion }\end{array}$ & Homestead size & $y=0.0006 x^{3}-0.0137 x^{2}+0.194 x$ & $\begin{array}{l}\text { Captures the impact of previous land fragmentation on current } \\
\text { newcomer rates, since smaller plot sizes reduces land } \\
\text { development potential. }\end{array}$ & Acequia Community \\
\hline $\begin{array}{l}\text { Land use preference due to } \\
\text { time allocation }\end{array}$ & $\begin{array}{l}\text { Monthly hours (labor) } \\
\text { in agriculture }\end{array}$ & $y=5 \times 10^{-7} x^{3}-1 \times 10^{-4} x^{2}-0.0009 x+0.9098$ & $\begin{array}{l}\text { Captures the type of agricultural enterprise preferred based on } \\
\text { irrigators time allotment. Less time in agriculture prefers pasture grass, } \\
\text { while more time allocates more to grains/vegetables and orchards. }\end{array}$ & Land Use \\
\hline $\begin{array}{l}\text { Mutualism effect on time } \\
\text { spent in acequia area-valley }\end{array}$ & Acequia mutualism & $y=x$ & $\begin{array}{l}\text { Captures the impact that acequia community engagement has on an } \\
\text { individual's allocation to time in agriculture, as the level of } \\
\text { engagement of remaining community members has a positive effect of } \\
\text { each other's decision to work in the acequia. }\end{array}$ & $\begin{array}{l}\text { Economics and } \\
\text { Time Management }\end{array}$ \\
\hline $\begin{array}{l}\text { Ratio of wage income in } \\
\text { agriculture to external jobs }\end{array}$ & $\begin{array}{l}\text { Ag profit/Opportunity } \\
\text { cost of Labor }\end{array}$ & $\begin{array}{c}x<0 \rightarrow \\
y=0.0129 x+0.099 \rightarrow \\
y=-0.008 x^{4}+0.1103 x^{3}-0.5279 x^{2}+1.0099 x+0.1206\end{array}$ & $\begin{array}{l}\text { Captures to opportunity costs of working off-farm jobs relative to what } \\
\text { financial returns are likely to be made on-farm. More positive values } \\
\text { place more preference on agriculture, more negative values } \\
\text { less preference. }\end{array}$ & $\begin{array}{l}\text { Economics and } \\
\text { Time Management }\end{array}$ \\
\hline $\begin{array}{l}\text { Short term profitability } \\
\text { effect on land sales }\end{array}$ & $\mathrm{Ag}$ profit/Land lease rate & $y=0.209 x^{2}-0.2084 x+0.0498$ & $\begin{array}{l}\text { Captures the short-term economic pressure to sell land if ag profit does } \\
\text { not meet the land's required rate of return (the lease rate). }\end{array}$ & Land Use \\
\hline
\end{tabular}


To compliment the analysis of the socio-cultural processes, several biophysical sensitivity tests were run using parameters of uncertain magnitude related to grazing (land area required per animal unit, shown as acres/AU; months needed to feed; and animal winter feed demand per animal month, shown as months feed needed) and hydrological processes (minimum streamflow delivery rate and percentage of normal acequia seepage). Grazing parameters were altered $+/-50 \%$ from the calibrated values (representing favorable or unfavorable upland conditions and variability in animal performance). For hydrological parameters, the minimum streamflow delivery rate was raised $(+400 \%$, representing possible regional policy changes) while the percentage of normal acequia seepage (calibrated at $100 \%$ of the observed seepage rates) was reduced $(-50 \%$; mimicking the impact of certain conservation strategies such as ditch lining). These ranges represented physically feasible ranges of conditions that have been or could be observed in acequia irrigation systems and the surrounding uplands that support grazing. More importantly, sensitivity tests of physical system parameters allowed for checks of model consistency to ensure the produced behaviors resulting from varying system conditions followed more intuitive dynamics, where local and scientific knowledge and understanding was greater than that of the qualitative factors.

\section{Results and Discussion}

\subsection{Calibration Analysis of Behavior Reproduction and Theil Inequality Tests}

Using several statistical measures (correlation coefficient, mean bias, Theil inequality statistics) we evaluated the model calibration (i.e., model fine tuning/fitting [51]) and began moving towards validation. Other than hydrologic inflows and climate parameters, real world observations were only used to estimate model initial conditions, so that the model did not heavily rely on input data to predetermine the output behavior of key variables. Model variables used for model evaluation included agricultural profit, stream flow, cattle herd size, irrigated and residential land, and community population.

Predicted agricultural (farm level) profit (an index that integrates several other reference modes) was compared to Rio Arriba county agricultural profit trends over the period 1969-2008 (Figure 13). Pearson correlation coefficient (r), a measure of goodness for behavior reproduction, was 0.5635 $\left(\mathrm{r}^{2}=0.32\right)$, while mean bias (a measure of overall accuracy) was $10.25 \%$. Correlation and accuracy between observed and predicted stream flows, cattle herd sizes, irrigated acreage in the acequia, residential land in the acequia, and riparian habitat are provided in Table 5. The final model reference mode, community population, lacked annual data points needed to find a more appropriate model fit, however, beginning and ending values match well (Figure 14). Describing acequias in the array of variables we have and in a quantitative way is a novel result in itself, and without such performance sensitivity tests would not have been possible.

Table 5. Calibration measures for behavior reproduction $\left(\mathrm{r}^{2}\right)$ and systemic errors (ending Theil inequality values).

\begin{tabular}{cccccc}
\hline \multicolumn{7}{c}{ Calibration Estimates } \\
\hline Variable & $\mathbf{r}^{2}$ & Mean Bias & Mean & Variance & Covariance \\
\hline Ag Profit & 0.51 & $10.25 \%$ & 0.000 & 0.029 & 0.971 \\
Stream flow & 0.99 & $10.2 \%$ & 0.008 & 0.279 & 0.713 \\
Cattle herd size & 0.85 & $0.001 \%$ & 0.351 & 0.482 & 0.167 \\
Irrigated acreage & 0.96 & $3.30 \%$ & 0.225 & 0.457 & 0.318 \\
Residential land (\%) & 0.98 & $0.29 \%$ & 0.343 & 0.343 & 0.314 \\
Riparian habitat & 0.75 & $3.10 \%$ & 0.225 & 0.500 & 0.275 \\
Community pop. & 0.19 & $6.45 \%$ & - & - & - \\
\hline
\end{tabular}




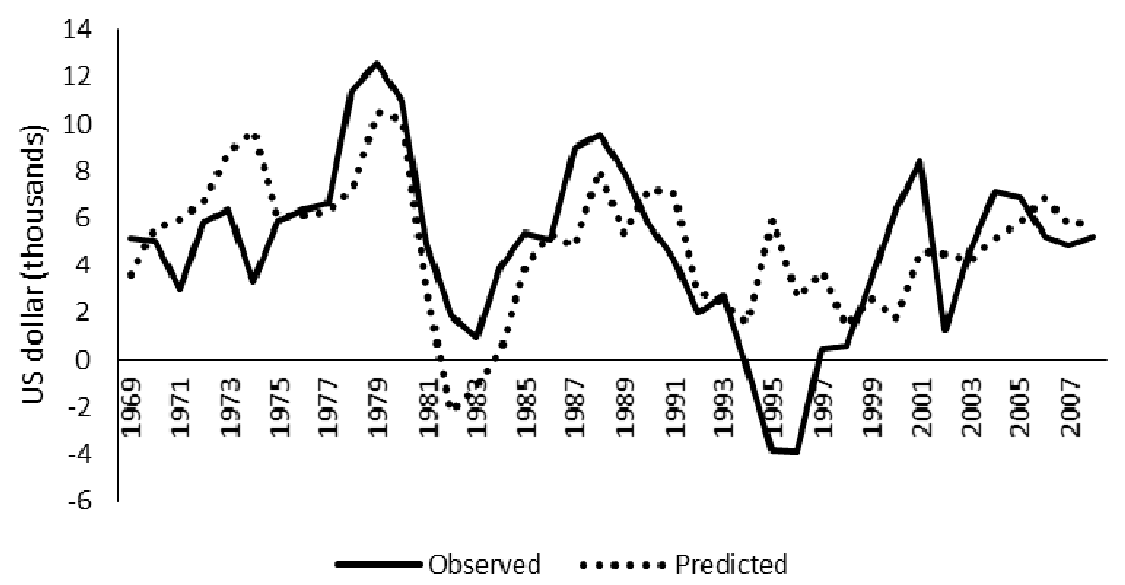

Figure 13. Observed county profit trends and predicted acequia agricultural profitability.

\section{Community population}

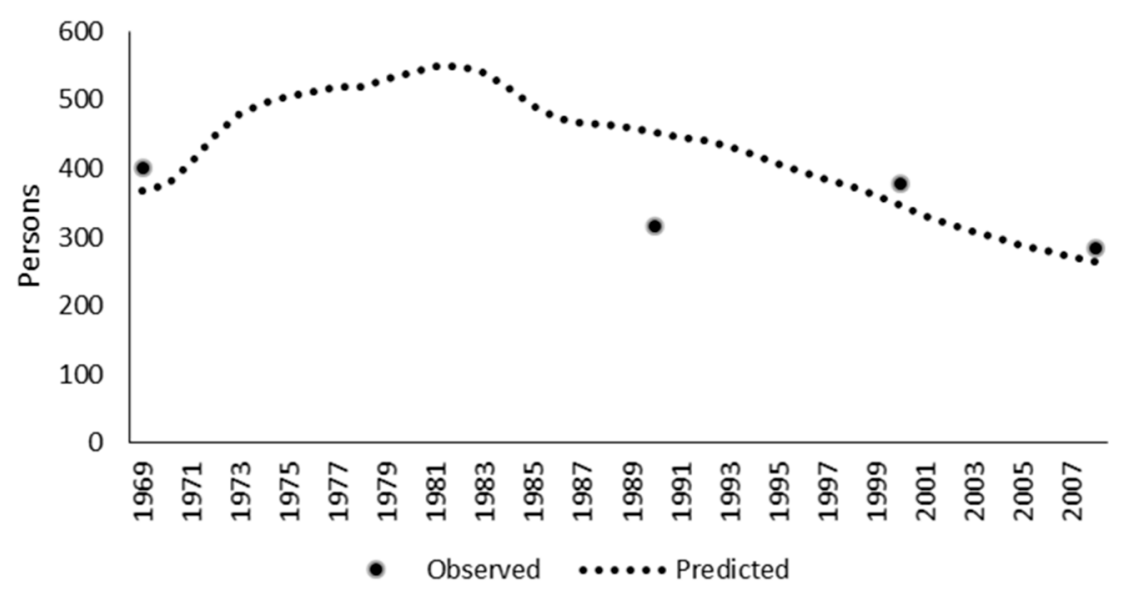

Figure 14. Observed and predicted community population in Alcalde, NM.

Although agricultural profitability showed a low correlation value (i.e., limited ability to mimic point-by-point observed data), resulting Theil inequality values showed systemic similarity between observed and predicted values (Table 5). Ending model bias estimates were 0.000 (mean), 0.029 (variance), and 0.971 (covariance), showing the model was able to adequately capture average profit values and variability of historical trends. Some of the model bias (particularly during the first half of the simulation; Figure 15) was expected since agricultural prices used in the profit function are U.S. national averages (alfalfa, wheat, cattle) and orchard prices derived in a different geographic region (Washington state, U.S., for which data were available over the simulation horizon). These predicted values can certainly be improved with local price data for all commodities of interest, however data sources for such inputs appear to be lacking or sporadic in nature.

Most of the model bias in stream flows is expressed in the covariance (0.713) and variance (0.279) of predicted values, while mean bias was remarkably low (0.0008), indicating low systematic errors in the hydrology components in the model. Cattle herd sizes and land use (irrigated land, percent in residential, riparian habitat) predictions had significantly higher error in means compared to agricultural profit and stream flows, however, the majority of errors remained in unequal variances and covariance (Table 5). These results indicated that there are gains in model performance that might be achieved with investments in model formulation and expansion of the cattle herd and 
land use parameters, but the current errors do not limit implementation of the model for scenario testing or outreach activities. No Theil values are reported for community population due to insufficient population data, which is generally provided on a decadal rather than annual basis. Overall, the calibration statistics (Table 5) of the acequia model was comparable to other SD models (e.g., [53-58]. Although no SD model will recreate reality, it can be deemed useful for its intended purpose (in our case scenario testing to investigate acequia community's places of resilience and vulnerability) upon successful model evaluation [51,59].

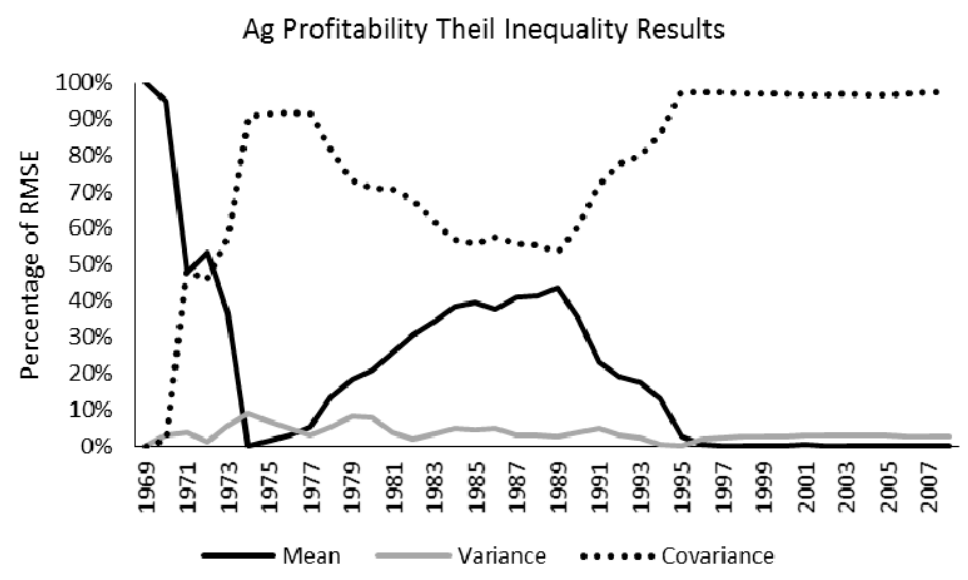

Figure 15. Evolution of Theil inequality values for agricultural profitability over the course of the simulation.

The model evaluation just described showed successful calibration of model outputs against multiple observed data sets. In the context of model validation, which is only a partial assessment of the usefulness of the model [51,59] and the degree to which it fulfills its purpose [51], there are three tasks: verification (internal checking of consistency within the computer program), sensitivity analysis (behavior of each model component), and evaluation (comparison of model outcomes to real data) [59]. Given internal consistency checks performed during model development (e.g., dimensional and units consistency) and the evaluation to observed data, we then moved to sensitivity analysis to better understand the model's behavior arising from extreme or varying conditions outside the scope of real world experience, as well as better understand the endogenous feedback loop structure at work in the model. However, prior to future model applications (e.g., forecasting of policy and management scenario in the face of economic and climate changes), further model validation should be evaluated based on updated data from the end of the calibration period (2009) to the present, to ensure that model behavior continues to replicate observed patterns.

\subsection{Sensitivity Analyses}

The sensitivity analyses undertaken here provided insights into model behavior from varying characteristics within the acequia system to gain a clearer understanding of the importance of certain socio-cultural processes that were expressed as graphical functions with little or no data available for parameterization and calibration. Results of the sensitivity analysis are given in Table 6 . Four socio-cultural processes created no or little numerical sensitivity and were eliminated after the first screening. Three other processes were eliminated after the second screening as changing their respective coefficient values caused small numerical sensitivities but no major shifts in trends or behaviors over time. The remaining three processes (Absentee decisions; Cumulative income effect on time in agriculture; Land use preference due to time allocation) were found to have the greatest impact on model behavior, as varying coefficient values created both numerical and behavioral changes in model outputs over time. Plots for land use preference due to time allocation and absentee decisions (variables that shift the ratio of pasture, alfalfa, vegetables, and orchards; or brings land into and out of production) 
are shown (Figure 16). Comparatively, several major differences were observed between land use and agricultural profitability. For example, land use preference changes did not have a large impact on irrigated land, but did create large downside risk-exposure in agricultural profitability as land use moved away from higher valued crops to pasture used for hay production. Alternatively, restricting absentee decisions limited any newcomers into the community (and therefore any expansions in residential/built up land). Without major residual shifts, land was able to remain under irrigation and irrigators maintaining a larger working farm size, which increased production and ability to capture agricultural profits.

Variables contributing to community participation (community demographic effect, effect on employment on participation, and farm size effect on participation) were examined separately as all three act on the same variable (community participation index). Each of these socio-cultural process variables created both numerical and behavioral sensitivities in model outputs (Table 6). Interestingly, all four variables yield similar results (see community participation index plot in Figure 16). Although shifts in the output variables were observed, the magnitudes were not nearly as large as those seen in the other socio-cultural sensitivity tests, indicating that there potentially exists some features in the model's acequia mutualism component that limits larger fluctuations in model outputs. Change in leadership and Mayordomo strength (the leadership input variables effecting acequia mutualism; Figure 4) were then tested for comparison. Although acequia mutualism was sensitive to changes in the leadership parameters, only marginal impacts were seen in the reference mode variables, indicating that community participation index possessed a greater ability to impact acequia mutualism than did the leadership variables. However, this is not to say that leadership is not an important tenet of acequia resiliency given evidence speaking to the contrary $[7,8]$, only under the current formulation, less variability than expected was seen. More robust investigation into the leadership elements will be explored in a future modeling work.

Table 6. Sensitivity results by round of screening of socio-economic processes and community participation index variables used in Acequia mutualism.

\begin{tabular}{|c|c|c|c|c|c|c|}
\hline \multirow[b]{2}{*}{ Qualitative Parameters } & \multicolumn{6}{|c|}{ Change in Effect (Calibrated) Variables } \\
\hline & $\begin{array}{c}\mathrm{Ag} \\
\text { Profit }\end{array}$ & $\begin{array}{c}\text { Stream } \\
\text { Flow }\end{array}$ & $\begin{array}{l}\text { Herd } \\
\text { Size }\end{array}$ & $\begin{array}{c}\text { Ag } \\
\text { Land }\end{array}$ & $\begin{array}{l}\text { Built } \\
\text { Land }\end{array}$ & $\begin{array}{c}\text { Riparian } \\
\text { Habitat }\end{array}$ \\
\hline \multicolumn{7}{|l|}{ First screening elimination * } \\
\hline Generational transfer effect on land sales & No & No & No & No & No & No \\
\hline Homestead size effect of reducing urban expansion & Yes & No & No & No & Yes & No \\
\hline Short term profitability effect on land sales & No & No & No & No & No & No \\
\hline Herd reductions from reduced management & No & No & No & No & No & No \\
\hline \multicolumn{7}{|l|}{ Second screening elimination ** } \\
\hline Cumulative profit-loss effect on land sales & No & No & No & No & No & No \\
\hline Mutualism effect on time spent in acequia area-valley & Yes & Yes & Yes & Yes & Yes & Yes \\
\hline Ratio of wage income in agriculture to external jobs & Yes & Yes & Yes & Yes & Yes & Yes \\
\hline \multicolumn{7}{|l|}{ Remaining variables of interest $* * *$} \\
\hline Absentee decisions & Yes & No & No & No & Yes & No \\
\hline Cumulative income effect on time in agriculture & Yes & Yes & Yes & Yes & Yes & Yes \\
\hline Land use preference due to time allocation & Yes & No & No & No & Yes & Yes \\
\hline \multicolumn{7}{|l|}{ Community participation variables ${ }^{\#}$} \\
\hline Community demographic effect on participation & Yes & No & No & Yes & Yes & Yes \\
\hline Effect of employment on participation & Yes & No & No & Yes & Yes & Yes \\
\hline Farm size effect on participation & Yes & No & No & Yes & Yes & Yes \\
\hline
\end{tabular}

Note: * eliminated variables after first screening (little numerical and no behavioral sensitivity); ${ }^{* *}$ parameters passed first screening; eliminated after second screening (numerical but not behavioral sensitivity); *** parameters passed first and second screening; generated both numerical and behavioral sensitivity; \# participation index variables; parameters shown both numerical and behavioral sensitivity. 


\section{Land use preference due to time allocation $x^{2}$}

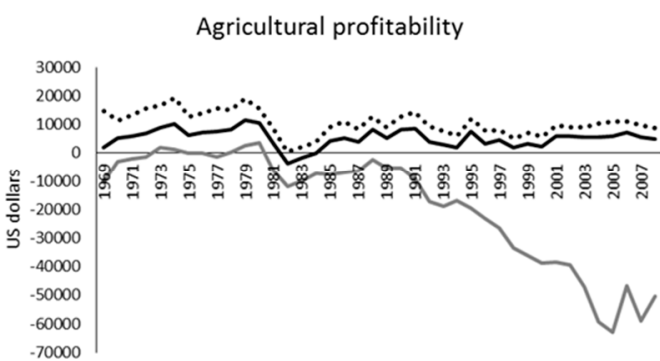

Irrigated land

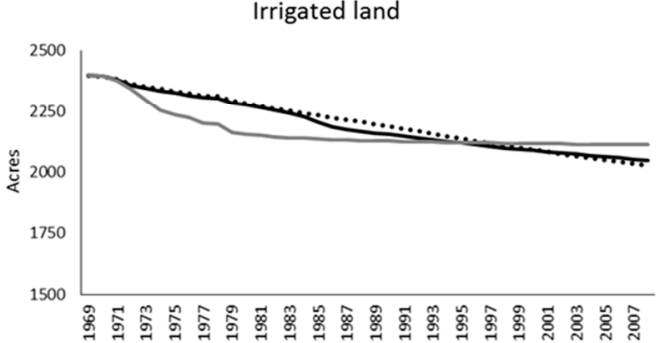

Residential/Built-up

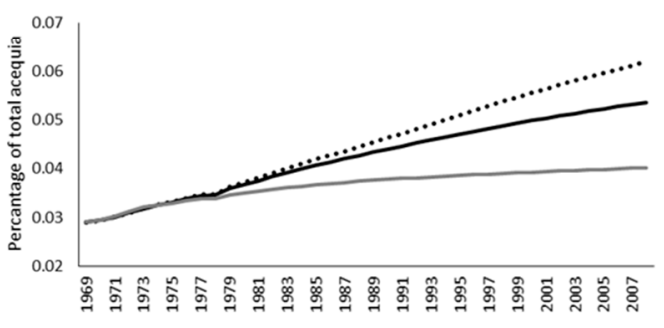

\section{Absentee decisions y-intercept}

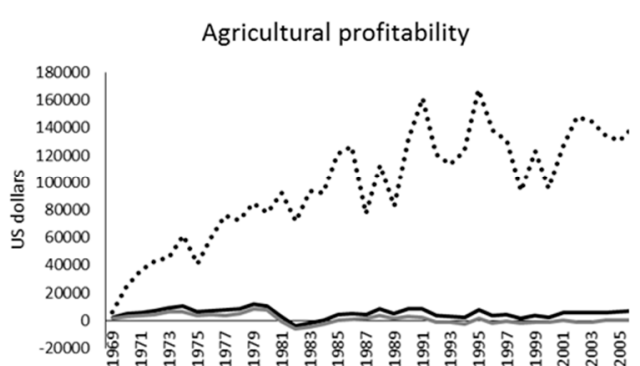

Irrigated land

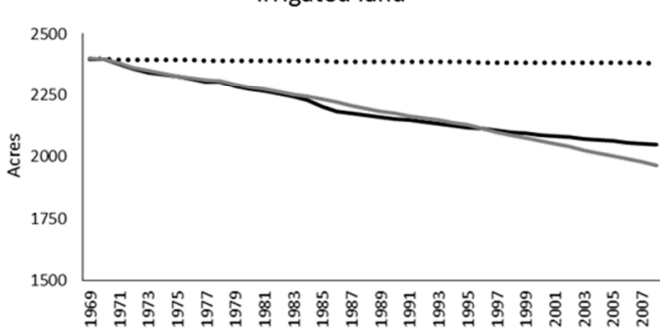

Residential/Built-up

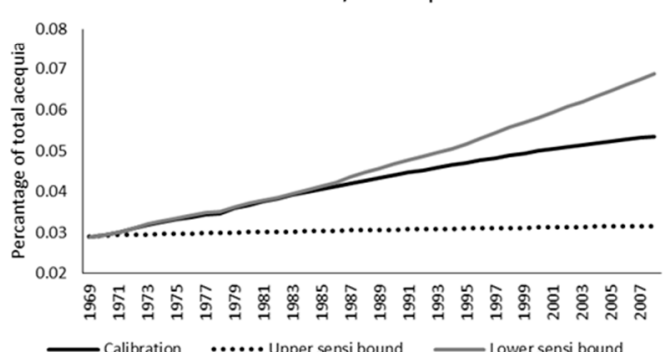

Community participation index variables

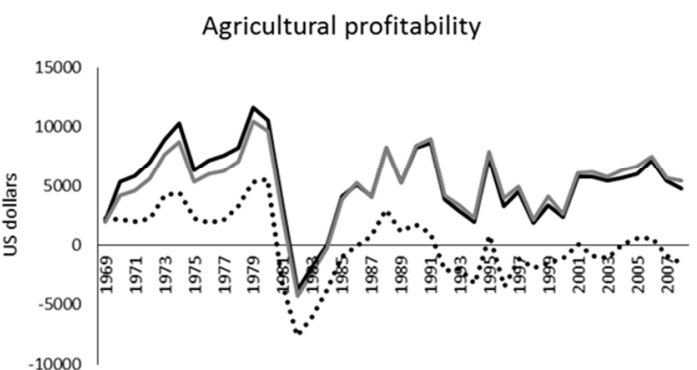

(2500

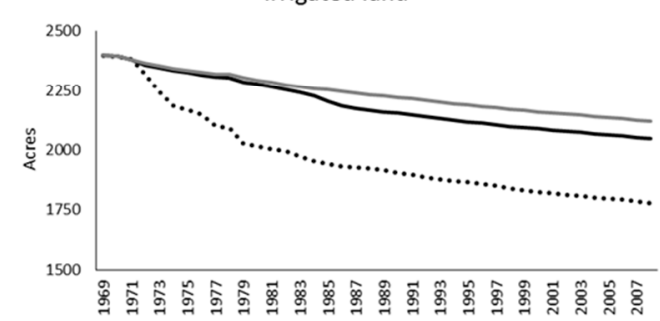

Residential/Built-up

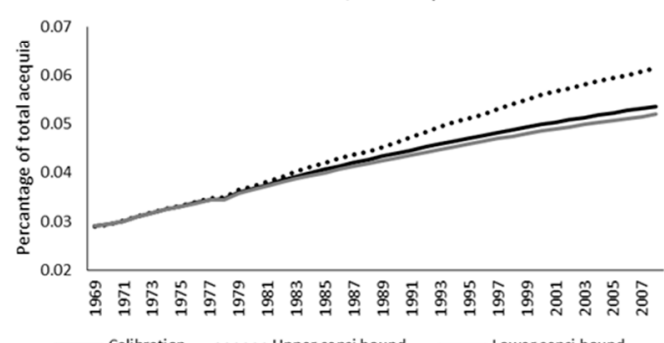

Figure 16. Sensitivity plots of key socio-economic variables that showed marked responses to changing input or parameter values (from Table 6), where upper and lower bounds refer to sensitivity bounds used during model testing. Plots for other variables expressing numerical sensitivity are shown in Figure S8. 
Several additional tests were run using biophysical model parameters where expectations of model behavior were more intuitive. Biophysical parameters tested centered on grazing (land area required per livestock animal unit (AU), generally one breeding animal weighing $454 \mathrm{~kg}$; annual winter feed demand per animal month; and months needed to feed) and hydrology (minimum streamflow delivery rate requirement, i.e., the maximum flow required before irrigation activities may take place); and percentage of normal acequia seepage rate, i.e., water percolated through the ditch during active irrigation). While each biophysical variable was well-defined and bounded within a limited range, impacts on the broader coupled system were uncertain. For example, changing land area per AU would intuitively impact cattle herd size (e.g., less land required would increase number of livestock), while increasing or reducing livestock feeding months or feed requirement per month (major economic drivers for cattle ranching) would have clearly defined impacts to agricultural profitability (e.g., decrease feed costs leads to increased profitability) but the extent of change in land use is much less certain. Significant differences were found in a number of tests (i.e. the percentage change between sensitivity output and calibrated values were larger than the calibrated mean bias) for agricultural profitability, cattle herd size, community population, residential land, and riparian habitat. Stream flow was not shown since only endogenous socio-economic or biophysical factors were emphasized for the sensitivity tests. Each biophysical sensitivity test is described in Table 7 with behavior-over-time plots of key relationships in Figures 17 and 18.

Table 7. Sensitivity values and results for each biophysical variable tested for comparison to model behavior resulting from qualitative parameter sensitivities.

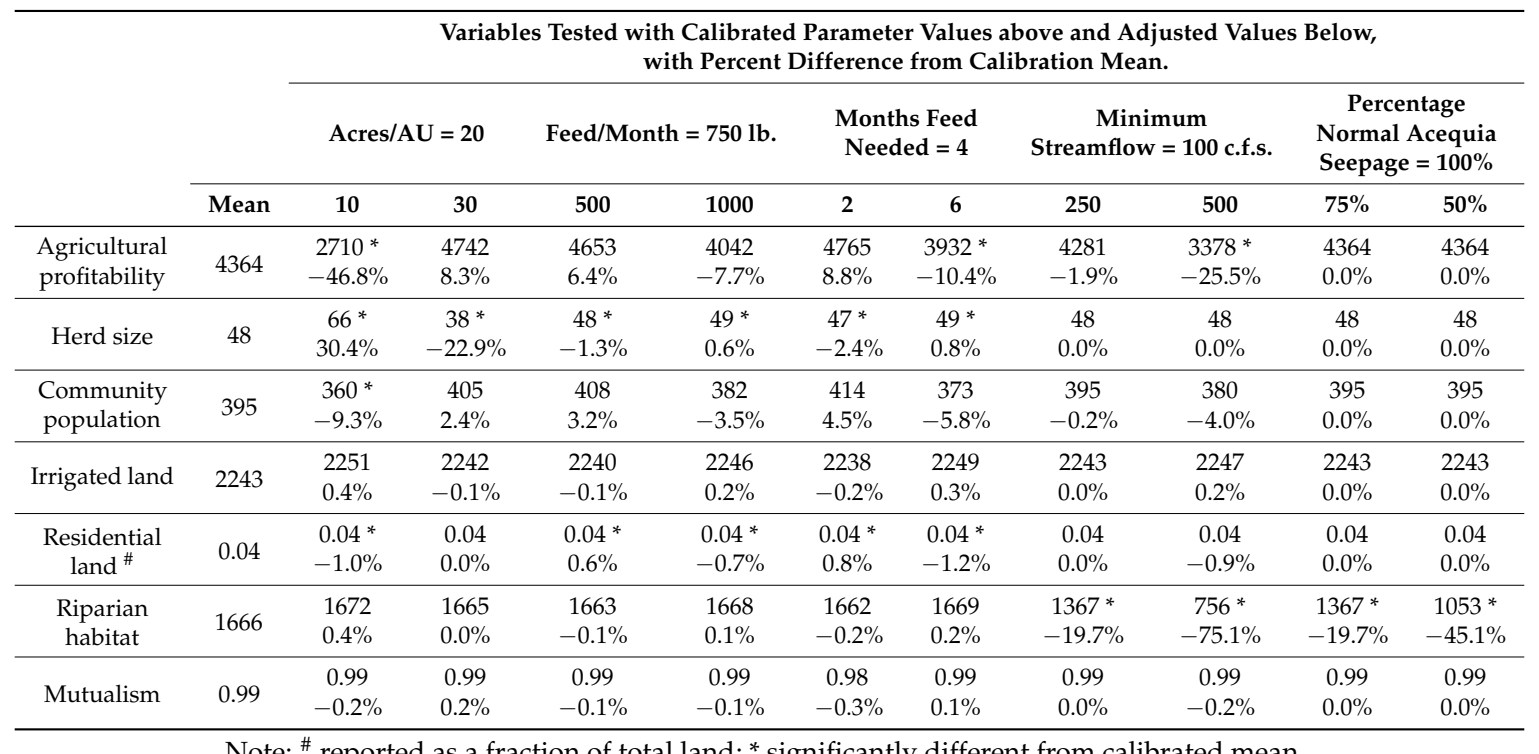

Note: ${ }^{\#}$ reported as a fraction of total land; ${ }^{*}$ significantly different from calibrated mean.

Overall, the results between socio-economic and biophysical variables were fairly consistent. Roughly $46 \%$ (36 out of 78; Table 6) of socio-economic parameters yielded some significant changes in model output, but only $28 \%$ (22 out of 78 ) resulted in both numerical and behavioral sensitivity. By comparison, 27\% (19 out of 70) of the biophysical tests showed significance, with $9 \%$ (6 out of 70; Figures 17 and 18) showing both numerical and behavioral sensitivity. However, the magnitude of model sensitivity changes were markedly greater during the socio-economic and community participation index tests (Figure 16). We anticipated greater uncertainty in these processes given the lack of previous models or quantitative data needed to refine parameter values. Also, when interpreting the behavior-over-time graphs, it is important to note the parameter space used to create the model behaviors. For socio-economic tests, values were altered up to an order of magnitude, while biophysical parameter values were increased or decreased only up to $50 \%$ (except for minimum 
streamflow requirement, +150 and $400 \%$ ). Variables that had the largest impact on the system as a whole point to areas that could place additional risk or stress to the acequia community system as well as likely favorable places to intervene to improve system behavior. Upon our analyses, such variables included absentee decisions (i.e., keeping people on the land), land use preference due to time allocation (i.e., balancing time in agriculture with commodities of high value), and community participation (i.e., maintaining balancing demographic and agriculture shifts to insure participation is still valued and practiced in the community).
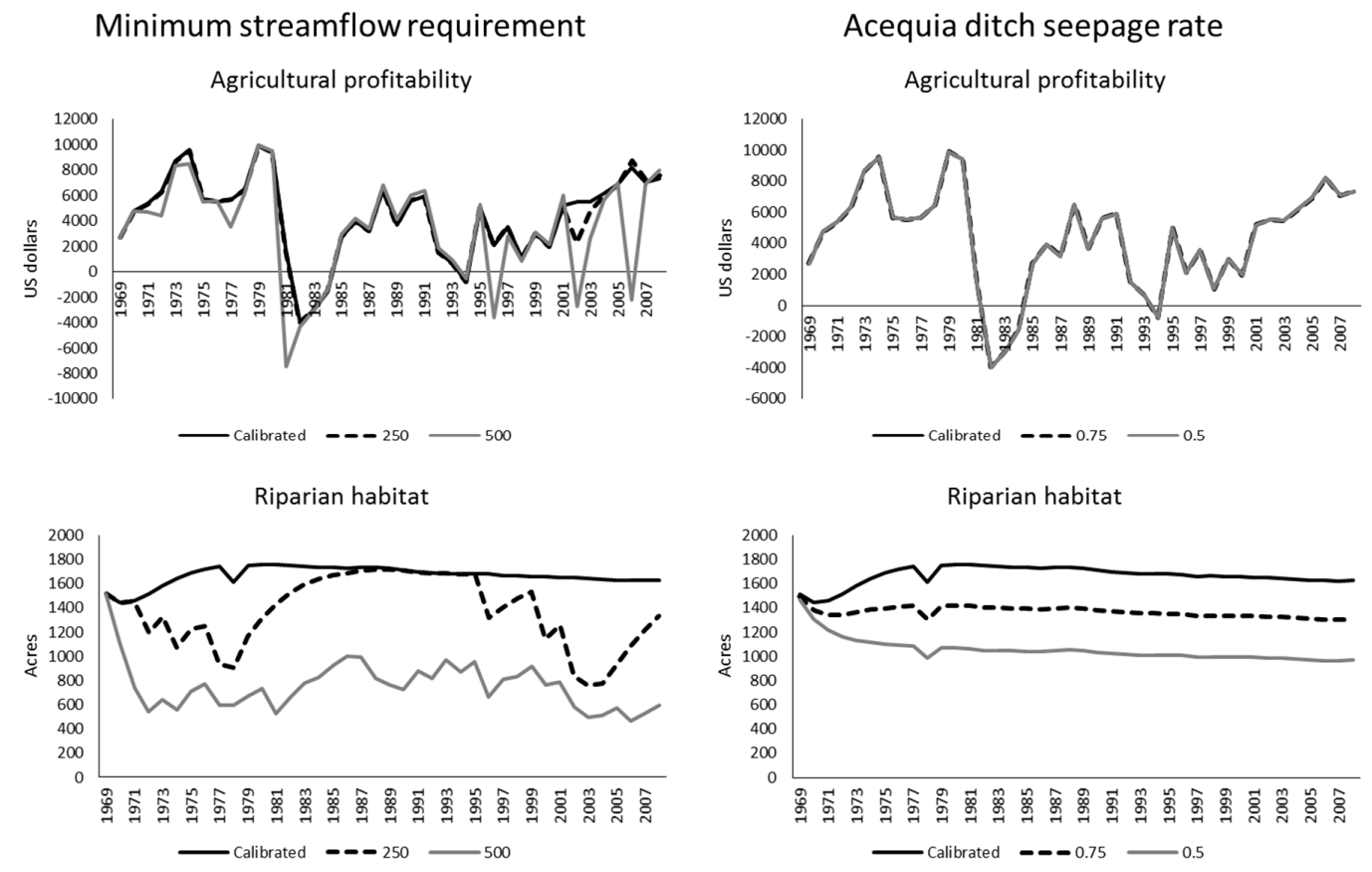

Figure 17. Physical parameter sensitivity tests in the acequia irrigation component of the model.

\subsection{Contributions to and Implications for Advancing Knowledge about Acequias}

Our model adds another valuable application of a sociohydrologic framework, applied through system dynamics methodology, which should add to the growing body of literature regarding the generic structures regulating socio-hydrologic connections (e.g., mutualism). Confidence in the model was generated through calibration and sensitivity analyses in order to examine model behavior and identify novel insights that could aid in future scenario development and interpretation. The sensitivity test results demonstrated a wide variety of behavioral responses from both socio-economic and biophysical factors. Several key learning points could be summarized from the analysis:

- A large number of socio-economic parameters showed only small numerical sensitivities in model outputs (Table 6). This is useful since many of the anecdotal leverage points identified by acequia researchers has hinged on socio-economic factors but with little confidence about which factors are expected to be more impactful than others. Our initial results give the first model-driven prioritization of socio-economic factors capable of changing behavior of multiple acequia components as well as identifies several gaps in available data (e.g., community demographic and employment effect on acequia participation; cumulative income effect on time spent in agriculture) that, if closed, would likely yield extremely valuable new qualitative insights and allow model refinement in the future.

- Agricultural profitability and land uses (agricultural or residential/built-up) were strongly influenced by time management of irrigators (i.e., decisions to commute outside the acequia for work; a function of agricultural activities, land use preference, and acequia mutualism). 
As irrigators continue to struggle to maintain profitability, more time is spent away from the acequia, which shifts land use preferences and therefore agricultural revenue potential, which provided fewer incentives to maintain land in agriculture.

- Although fewer sensitive outputs were identified from the biophysical tests, those biophysical parameters that did cause sensitivities highlight key system linkages needed to understand potential impacts to acequias in the future. For example, changes in acres per animal unit, feed required per month, months needed to feed livestock, or minimum streamflow requirement created sensitivities in agricultural profitability, cattle herd size, community size, or residential land, each with similar pathways identified during socio-economic parameter tests, particularly cascading and reinforcing dynamics among agricultural profit (e.g., grazing parameters shifted cattle herd size $\rightarrow$ cattle herd size was linked to agricultural profit $\rightarrow$ agricultural profit feedbacks to herd expansion or culling decisions; community size was linked to community demographics and residential land $\rightarrow$ residential land was linked to irrigated land $\rightarrow$ irrigated land was linked agricultural profit $\rightarrow$ agricultural profit feedbacks to adjust time in agriculture and therefore irrigated land). Such physical leverage points (grazing area; water availability) have also been quantified in similar sociohydrology models (e.g., [20,21]).

- Although most data pertaining to irrigator time management, land use decisions, and acequia mutualism has remained qualitative in nature, the importance of these variables and their relationship to acequia mutualism has been stressed (e.g., [4,7,8]). Our model is the first quantitative, process based framework that corroborates those findings, while also identifying several key socio-economic processes that are likely the leading indicators of acequia resilience (community demographics, irrigator employment and time management, and farm size) and which to devote future research efforts.

- Therefore, the importance of community participation and acequia mutualism are critical for understanding the physical, social, and economic dynamics occurring within acequia communities (which corroborates similar applied sociohydrology models [18-21]). The linkages described and sensitivities identified highlight important areas of risk as well as leverage points that can effect change to the acequia community system (e.g., altering time spent in agriculture can effect change in acequia land use, community, hydrology, and mutualism), which should prove useful during future stakeholder outreach opportunities as well as modeling applications, including scenario testing to identify areas of resiliency and vulnerability of acequias from internal factors, climate change and urbanization.

A key contribution of this model was the incorporation of a number of socio-economic and cultural variables (connected through a similar socio-hydrologic perspective developed by [18-21]), whose dynamics of interest are fairly well understood historically but where little- to no quantitative data exists to inform the model (e.g., how irrigators manage their time or how demographics effect mutualism). While confidence in the model was developed through comparisons drawn with reference modes, lack of data in a large number of these processes added an additional layer of uncertainty to the model. In many other modeling circumstances, such data limitations may be considered model weaknesses and future emphases are placed in generating increased data with greater specificity. This remains problematic for acequia modeling research since much of the desired data resides in the human dimensions of the acequia system and determining how to quantify results into a working model remains challenging. For these reasons, we took a systems modeling approach and tested the sensitivity of uncertain parameters for which better quantitative description is unlikely (for reasons noted above) but which equally fit the observed historical data that was available. Not only was the variability regarding these parameters quantified but several socio-cultural leverage points were identified through the process (e.g., enhancing community participation). The knowledge gained regarding the variability of model behaviors will be carried forward to interpret acequia community response to disruptive events and adoption of adaptive strategies. However, the creative capacity of acequia communities and leaders likely exceeds the knowledge embedded within the historical 
record. For this reason, modeling of community adaptations must be done in tandem with acequia stakeholders, who in real-time have the capacity to anticipate upcoming challenges and create and manage novel strategies to address those challenges.

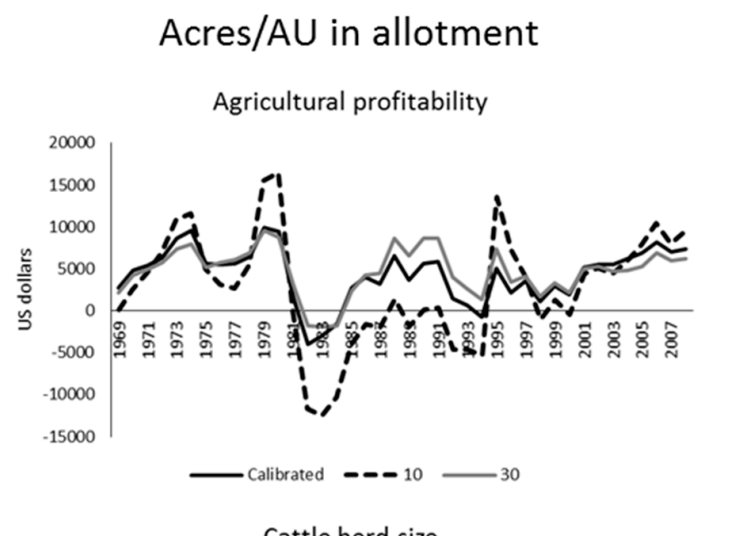

\section{Feeding months required}
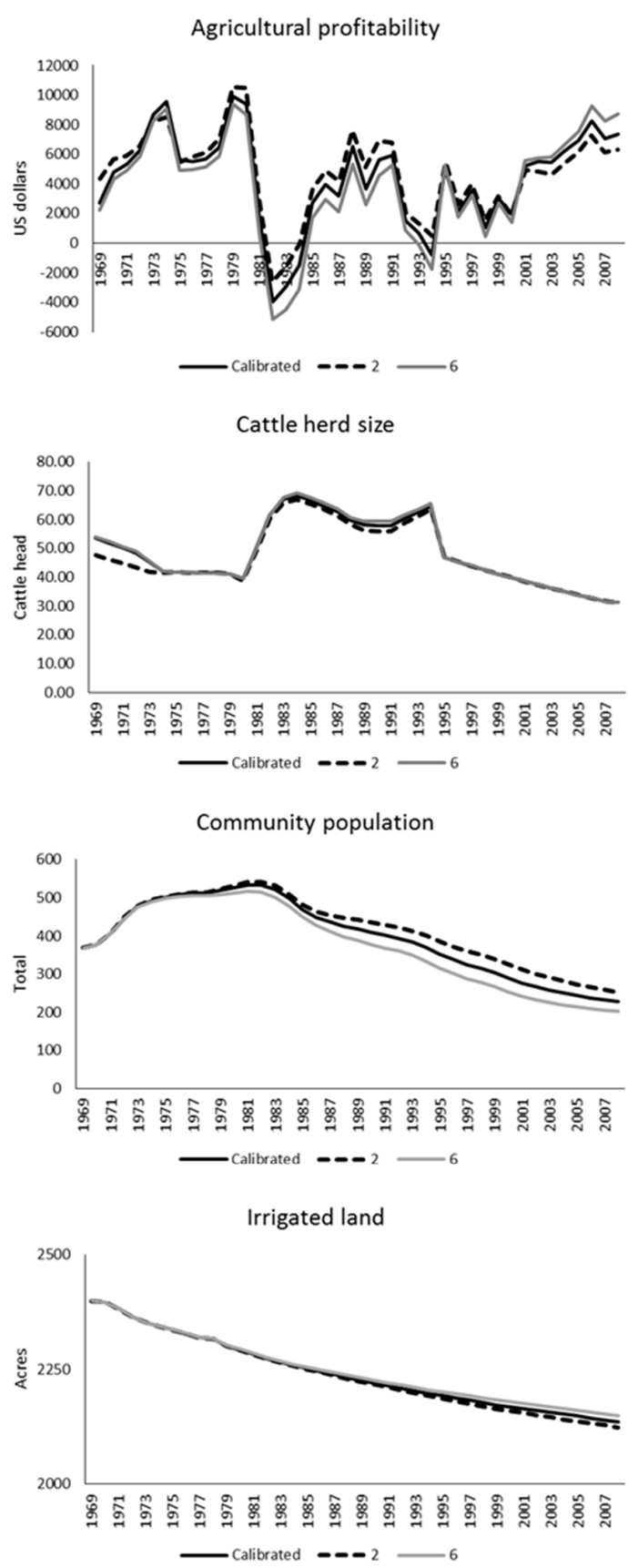

Figure 18. Physical parameter sensitivity tests in the cattle grazing component of the model.

\section{Conclusions}

A unique system dynamics model has been developed to investigate the resiliency of acequia communities in northern New Mexico. While knowledge of the complex interrelations of community, economics, ecology, and hydrology has advanced greatly in the last 25 years, no model to-date has coupled these diverse disciplines for scenario testing or robust analyses of potential system behavior 
in the face of continuous climate, economic, and social changes occurring in the southwestern U.S. We theorized that community sustainability and resilience were rooted in acequia-based connectivity, i.e., the interaction between acequia members (i.e., Acequia mutualism) and the land and water resources they manage.

Our model showed that physical, social, and economic indicators were strongly linked to acequia mutualism and the community participation variables. Specifically, results from our analyses have provided the first quantitative ranking of socio-economic and community variables, highlighted the important linkages between agricultural profitability and time management of irrigators, and showed a wide array of impacts stemming from community participation and time management decisions. Although fewer sensitive outputs were identified from the biophysical tests, those that did cause sensitive outputs highlight key system linkages between acequia structure and the behavior arising from that structure. Interestingly, significant biophysical parameters shared similar pathways as the socio-economic forces. Contributions of this work included: (a) quantification of important qualitative components of the acequia community irrigation system; (b) estimated values for those parameters producing the most sensitive output responses; and (c) feasible expansion in model boundaries of previous SD modeling attempts to include rigorous connections between hydrology, socio-economics, and community mutualism. The three socio-economic parameters that created both numerical and behavioral sensitivities indicated the importance of acequia mutualism and community participation as potential leverage points to acequia sustainability.

Lastly, previous modeling attempts have limited model boundaries to physical stocks and flows, and restricted or neglected the importance of acequia mutualism. The model boundary we've explored makes it possible for future testing to include changes in acequia policies and relationships. The completed model for Alcalde, NM was developed in an extensible manner and thus can be extended to investigate other acequia systems. As additional communities are modeled their aggregate impacts downstream on the Rio Grande will be explored [42]. Additional work is in progress to couple the acequia model to the upland watershed (runoff generation, vegetation change, and grazing dynamics). This will broaden the audience and model users from acequia communities alone to include regional stakeholders and public policy makers. Extension to incorporate future climate and economic scenarios will provide a means for testing acequia strength, resiliency, and adaptability in aims of successfully navigating the anticipated challenges that threaten their way of life.

Supplementary Materials: The following are available online at www.mdpi.com/2071-1050/8/10/1019/s1, Figure S1: Symbols key of icon-based object used to construct the acequia SD model, Table S1: Key model equations for the Community Mutualism system building block, Table S2: Key model equations for the Land Use system building block, Table S3: Key model equations for the Economics and Time Management system building block, Table S4: Key model equations for the Cattle Production (part of the Farm and Ranch system building block), Table S5: Key model equations for the Forage Inventory (part of the Farm and Ranch system building block), Table S6: Key model equations for the Acequia Irrigation Diversion (part of the Acequia Hydrology system building block), Table S7: Key model equations for the Surface Water-Groundwater Interactions (part of the Acequia Hydrology system building block), Table S8: Key model equations for the Ecosystem Health system building block, Table S9: Key model equations for the Acequia Community system building block, Figure S2: Variables used in the construction of the community participation index, Figure S3: Variables used to link changes in community to land use through the residential development rate variable, Figure S4: Variables used to link various system building blocks, Figure S5: Variables used in the Economics and Time Management system building block, Figure S6: Variables used in construction of the cattle herd production components, Figure S7: Variables used in partitioning water in the Acequia Hydrology system building block, Figure S8: Variables used in applying irrigation from the Acequia Hydrology to the Farm and Ranch system building block, Figure S9: Additional sensitivity plots of socio-economic processes.

Acknowledgments: This project was funded by the National Science Foundation's Program on the Dynamics of Coupled Natural \& Human Systems; grant \#1010516. General support was also provided by the New Mexico State University Agricultural Experiment Station. We also thank three anonymous reviewers for their helpful comments and suggestions of the manuscript.

Author Contributions: Benjamin L. Turner developed the model and conducted the calibration and sensitivity tests. Vincent Tidwell assisted in model development and designed the sensitivity analyses. Alexander Fernald, Jose A. Rivera, Sylvia Rodriguez, Steven Guldan, Carlos Ochoa, Brian Hurd, Kenneth Boykin and Andres Cibils provided expert knowledge used to develop Sections 2.4.1-2.4.7, as well as data used for model calibration, 
evaluation, and sensitivity tests. Benjamin L. Turner and Vincent Tidwell designed and wrote the paper while Alexander Fernald, Jose A. Rivera, Sylvia Rodriguez, Steven Guldan, Carlos Ochoa, Brian Hurd, Kenneth Boykin and Andres Cibils critiqued the model results and manuscript prior to submission.

Conflicts of Interest: The authors declare no conflict of interest.

\section{References}

1. Ackerly, N.W. A Review of the Historic Significance and Management Recommendations for Preserving New Mexico's Acequia Systems; Historic Preservation Division: Santa Fe, NM, USA, 1996.

2. Mayagoitia, L.; Hurd, B.; Rivera, J.; Guldan, S. Rural Community Perspectives on Preparedness and Adaptation to Climate-Change and Demographic Pressure. J. Contemp. Water Res. Educ. 2012, 147, 49-62. [CrossRef]

3. Fernald, A.; Tidwell, V.; Rivera, J.; Rodriguez, S.; Guldan, S.; Steele, C.; Ochoa, C.; Hurd, B.; Ortiz, M.; Boykin, K.; et al. Modeling Sustainability of Water, Environment, Livelihood, and Culture in Traditional Irrigation Communities and Their Linked Watersheds. Sustainability 2012, 4, 2998-3022. [CrossRef]

4. Fernald, A.G.; Baker, T.T.; Guldan, S.J. Hydrologic, Riparian, and Agroecosystem Functions of Traditional Acequia Irrigation Systems. J. Sustain. Agric. 2007, 30, 147-171. [CrossRef]

5. Fernald, A.G.; Yeliz Cevik, S.; Ochoa, C.G.; Tidwell, V.C.; Phillip King, J.; Guldan, S.J. River Hydrograph Retransmission Functions of Irrigated Valley Surface Water-Groundwater Interactions. J. Irrig. Drain. Eng. 2010, 136, 823-835. [CrossRef]

6. Cox, M.; Ross, J.M. Robustness and vulnerability of community irrigation systems: The case of the Taos Valley acequias. J. Environ. Econ. Manag. 2011, 61, 254-266. [CrossRef]

7. Rodrigeuz, S. Acequia: Water Sharing, Scarcity, and Place; School for Advanced Research Press: Santa Fe, NM, USA, 2006.

8. Rivera, J.A. Acequia Culture: Water, Land, and Community in the Southwest; University of New Mexico Press: Albuquerque, NM, USA, 1998.

9. Brierly, G.; Fryirs, K.; Vikrant, J. Landscape connectivity: the geographic basis of geomorphic applications. Area 2006, 38, 165-174. [CrossRef]

10. US Bureau of Economic Analysis. Regional Economic Accounts, Tables CA25 and CA25N, Total Employment by Major SIC (NAICS) Industry. 2013. Available online: http://bea.gov/regional/downloadzip.cfm (accessed on 18 October 2013).

11. US Bureau of Economic Analysis. Regional Economic Accounts, Table CA45, Farm Income and Expenses. 2013. Available online: http://bea.gov/regional/downloadzip.cfm (accessed on 18 October 2013).

12. Sabie, R.; Cruz, J.J.; Turner, B.L.; Moreno, A.L.; Hewitt, L. Land use assessment of acequia irrigated valleys using multi-date aerial imagery. In Proceedings of the American Water Resources Association Annual Conference, Denver, CO, USA, 16-19 November 2015.

13. Fernald, A.G.; Guldan, S.J. Surface Water-Groundwater Interactions between Irrigation Ditches, Alluvial Aquifers, and Streams. Rev. Fish. Sci. 2006, 14, 79-89. [CrossRef]

14. Ochoa, C.G.; Fernald, A.G.; Guldan, S.J.; Shukla, M.K. Deep Percolation and Its Effects on Shallow Groundwater Level Rise Following Flood Irrigation. Trans. Am. Soc. Agric. Biol. Eng. 2007, 50, $73-81$.

15. Ochoa, C.G.; Fernald, A.G.; Guldan, S.J.; Shukla, M.J. Water Movement through a Shallow Vadose Zone: A Field Irrigation Experiment. Vadose Zone J. 2009, 8, 414-425. [CrossRef]

16. Martinez-Fernandez, J.; Esteve-Selma, M.A.; Calvo-Sendin, J.F. Environmental and Socioeconomic Interactions in the Evolution of Traditional Lands: A Dynamic System Model. Hum. Ecol. 2000, 28, 279-299. [CrossRef]

17. Morrison, R.R.; Stone, M.C. Investigating environmental flows for riparian vegetation recruitment using system dynamics modelling. River Res. Appl. 2015, 31, 485-496. [CrossRef]

18. Elshafei, Y.; Sivapalan, M.; Tonts, M.; Hipsey, M.R. A prototype framework for models of sociohydrology: Identification of key feedback loops with application to two Australian casestudies. Hydrol. Earth Syst. Sci. 2014, 18, 2141-2166. [CrossRef]

19. Van Emmerik, T.; Li, Z.; Sivapalan, M.; Pande, S.; Kandasamy, J.; Savenije, H.H.G.; Chanan, A.; Vigneswaran, S. Socio-hydrologic modeling to understand and mediate the competition for water between agriculture development and environmental health: Murrumbidgee River basin, Australia. Hydrol. Earth Syst. Sci. 2014, 18, 4239-4259. [CrossRef] 
20. Pande, S.; Savenije, H.H.G. A sociohydrological model for smallholder farmers in Maharashtra, India. Water Resour. Res. 2016, 52, 1923-1947. [CrossRef]

21. Elshafei, Y.; Tonts, M.; Sivapalan, M.; Hipsey, M.R. Sensitivity of emergent sociohydrologic dynamics to internal system properties and external sociopolitical factors: Implications for water management. Water Resour. Res. 2016. [CrossRef]

22. Weinberg, G.M. An Introduction to General Systems Thinking; Wiley-Interscience: New York, NY, USA, 1975.

23. Jenerrette, G.D.; Barron-Gafford, G.A.; Guswa, A.J.; McDonnell, J.J.; Villegas, J.C. Organization of complexity in water limited ecohydrology. Ecohydrology 2012, 5, 184-199. [CrossRef]

24. Sterman, J.D. Business Dynamics: Systems Thinking and Modeling for a Complex World; McGraw-Hill: New York, NY, USA, 2000.

25. Tidwell, V.C.; Passell, H.D.; Conrad, S.H.; Thomas, R.P. System dynamics modeling for community-based water planning: Application to the Middle Rio Grande. Aquat. Sci. 2004, 66, 357-372. [CrossRef]

26. Stave, K.A. A system dynamics model to facilitate public understanding of water management options in Las Vega, Nevada. J. Environ. Manag. 2003, 67, 303-313. [CrossRef]

27. Khan, S.; Yufeng, L.; Ahmad, A. Analysing complex behaviour of hydrological systems through a system dynamics approach. Environ. Model. Softw. 2009, 24, 1363-1372. [CrossRef]

28. Shanshan, D.; Lanhai, L.; Honggang, X. The system dynamics study of regional development of Manas Basin under the constraints of water resources. In Proceedings of the 2010 International Conference of the System Dynamics Society, Seoul, South Korea, 25-29 July 2010.

29. Ewers, M.E. Combining Hydrology and Economics in a System Dynamics Approach: Modeling Water Resources for the San Juan Basin. In Proceedings of the 2005 International Conference of the System Dynamics Society, Boston, MA, USA, 17-21 July 2005.

30. Nandalal, K.D.; Simonovic, S.P. Resolving conflicts in water sharing: a systemic approach. Water Resour. Res. 2003, 39, 1362. [CrossRef]

31. Stave, K.A. Using system dynamics to improve public participation in environmental decisions. Syst. Dyn. Rev. 2002, 18, 139-167. [CrossRef]

32. Winz, I.; Brierly, G.; Trowsdale, S. The Use of System Dynamics Simulation in Water Resources Management. Water Resour. Manag. 2009, 23, 1301-1323. [CrossRef]

33. Van den Belt, M.J. Mediated Modeling-A System Dynamics Approach to Environmental Consensus Building; Island: Washington, DC, USA, 2004.

34. Tidwell, V.C.; van den Brink, C. Cooperative Modeling: Linking Science, Communication, and Ground Water Planning. Ground Water 2008, 46, 174-182. [CrossRef] [PubMed]

35. Deaton, M.L.; Winebrake, J.J. Dynamic Modeling of Environmental Systems; Springer Science + Business Media, Inc.: New York, NY, USA, 2000.

36. Grant, W.E.; Pedersen, E.K.; Marin, S.L. Ecology \& Natural Resource Management: Systems Analysis and Simulation; John Wiley \& Sons: New York, NY, USA, 1997.

37. Ford, A. Modeling the Environment; Island Press: Washington, DC, USA, 2009.

38. Alexrk. USA New Mexico Location Map. Wikipedia, Creative Commons Distribution. 2009. Available online: https://upload.wikimedia.org/wikipedia/commons/thumb/1/10/USA_New_Mexico_location_ map.svg/200px-USA_New_Mexico_location_map.svg.png (accessed on 31 August 2009).

39. "Alcalde, $\mathrm{NM}^{\prime \prime} 36^{\circ} 5^{\prime} 13.54^{\prime \prime} \mathrm{N}$ and $106^{\circ} 3^{\prime} 40.14^{\prime \prime} \mathrm{W}$. Google Earth, 2013 . Available online: https://www.google.com/maps/place/36\%C2\%B005'13.5\%22N+106\%C2\%B003'40.1\%22W/@36.0870987, $-106.0786595,4944 \mathrm{~m} /$ data $=! 3 \mathrm{~m} 1 ! 1 \mathrm{e} 3 ! 4 \mathrm{~m} 5 ! 3 \mathrm{~m} 4 ! 1 \mathrm{~s} 0 \times 00: 0 \times 0 ! 8 \mathrm{~m} 2 ! 3 \mathrm{~d} 36.0870944 ! 4 \mathrm{~d}-106.06115$ (accessed on 1 September 2015).

40. New Mexico Acequia Association. Regional Acequia Associations. Available online: http://www.lasacequias. org/wp/wp-content/uploads/2013/10/regional_associations_8.5x11.pdf (accessed on 7 July 2016).

41. Lane, D.C. Social theory and system dynamics practice. Eur. J. Oper. Res. 1999, 113, 501-527. [CrossRef]

42. Oliva, R. Model calibration as a testing strategy for system dynamics models. Eur. J. Oper. Res. 2003, 151, 552-568. [CrossRef]

43. Glover, C.R.; Foster, C.L.; Baker, R.D. Irrigated Pastures for New Mexico; Circular 494 New Mexico State Extension Service. 1997. Available online: http://cahe.nmsu.edu/pubs/_circulars/circ494.pdf (accessed on 29 November 2006). 
44. Steduto, P.; Hsiao, T.C.; Fereres, E.; Raes, D. Crop Yield Response to Water; Food and Agriculture Organization of the United Nations: Rome, Italy, 2012.

45. Roach, J.D. Integrated Surface Water Groundwater Modeling in the Upper Rio Grande in Support of Scenario Analysis. Ph.D. Thesis, University of Arizona, Tucson, AZ, USA, 19 March 2007.

46. Hargreaves, G.H. Moisture availability and crop production. Trans. ASAE 1975, 18, 980-984. [CrossRef]

47. Hargreaves, G.H.; Allen, R.G. History and evaluation of Hargreaves evapotranspiration equation. J. Irrig. Drain. Eng. ASCE 2003, 129, 53-63. [CrossRef]

48. Hargreaves, G.L.; Hargreaves, G.H.; Riley, J.P. Irrigation Water Requirements for Senegal River Basin. J. Irrig. Drain. Eng. ASCE 1985, 111, 265-275. [CrossRef]

49. Sterman, J.D. Appropriate summary statistics for evaluating the historical fit of system dynamics models. Dynamica 1984, 10, 51-66.

50. Oliva, R. A Vensim Module to Calculate Summary Statistics for Historical Fit. 1995. Available online: http:/ / metasd.com/wp-content/uploads/2010/03/D4584theil.pdf (accessed on 10 October 2016).

51. Tedeschi, L.O. Assessment of the adequacy of mathematical models. Agric. Syst. 2006, 89, 225-247. [CrossRef]

52. Eker, S.; Slinger, J.; van Daalen, E.; Yücel, G. Sensitivity analysis of graphical functions. Syst. Dyn. Rev. 2014, 30, 186-205. [CrossRef]

53. Pang, H.; Makarechian, M.; Basarab, J.A.; Berg, R.T. Structure of a dynamic simulation model for beef production systems. Can. J. Anim. Sci. 1999, 79, 409-417. [CrossRef]

54. Kahn, H.E.; Lehrer, A.R. A dynamic model for the simulation of cattle herd production systems: Part 3-Reproductive performance of beef cows. Agric. Syst. 1984, 13, 143-159. [CrossRef]

55. Tess, M.W.; Kolstad, B.W. Simulation of cow-calf production systems in a range environment: II model evaluation. J. Anim. Sci. 2000, 78, 1170-1180. [CrossRef] [PubMed]

56. Turner, B.L.; Rhoades, R.D.; Tedeschi, L.O.; Hanagriff, R.D.; McCuistion, K.C.; Dunn, B.H. Analyzing ranch profitability from varying cow sales and heifer replacement rates for beef cow-calf production using system dynamics. Agric. Syst. 2013, 114, 6-14. [CrossRef]

57. Turner, B.L.; Wuellner, M.; Nichols, T.; Gates, R.; Tedeschi, L.O.; Dunn, B.H. Development and Evaluation of a System Dynamics model for Investigating Agriculturally Driven Land Transformation in the North Central United States. Nat. Resour. Model. 2016, 29, 179-228. [CrossRef]

58. Van Horn, R.L. Validation of simulation results. Manag. Sci. 1971, 17, 247-258. [CrossRef]

59. Hamilton, M.A. Model validation: An annotated bibliography. Commun. Stat. Theory Methods 1991, 20, 2207-2266. [CrossRef]

(C) 2016 by the authors; licensee MDPI, Basel, Switzerland. This article is an open access article distributed under the terms and conditions of the Creative Commons Attribution (CC-BY) license (http://creativecommons.org/licenses/by/4.0/). 